
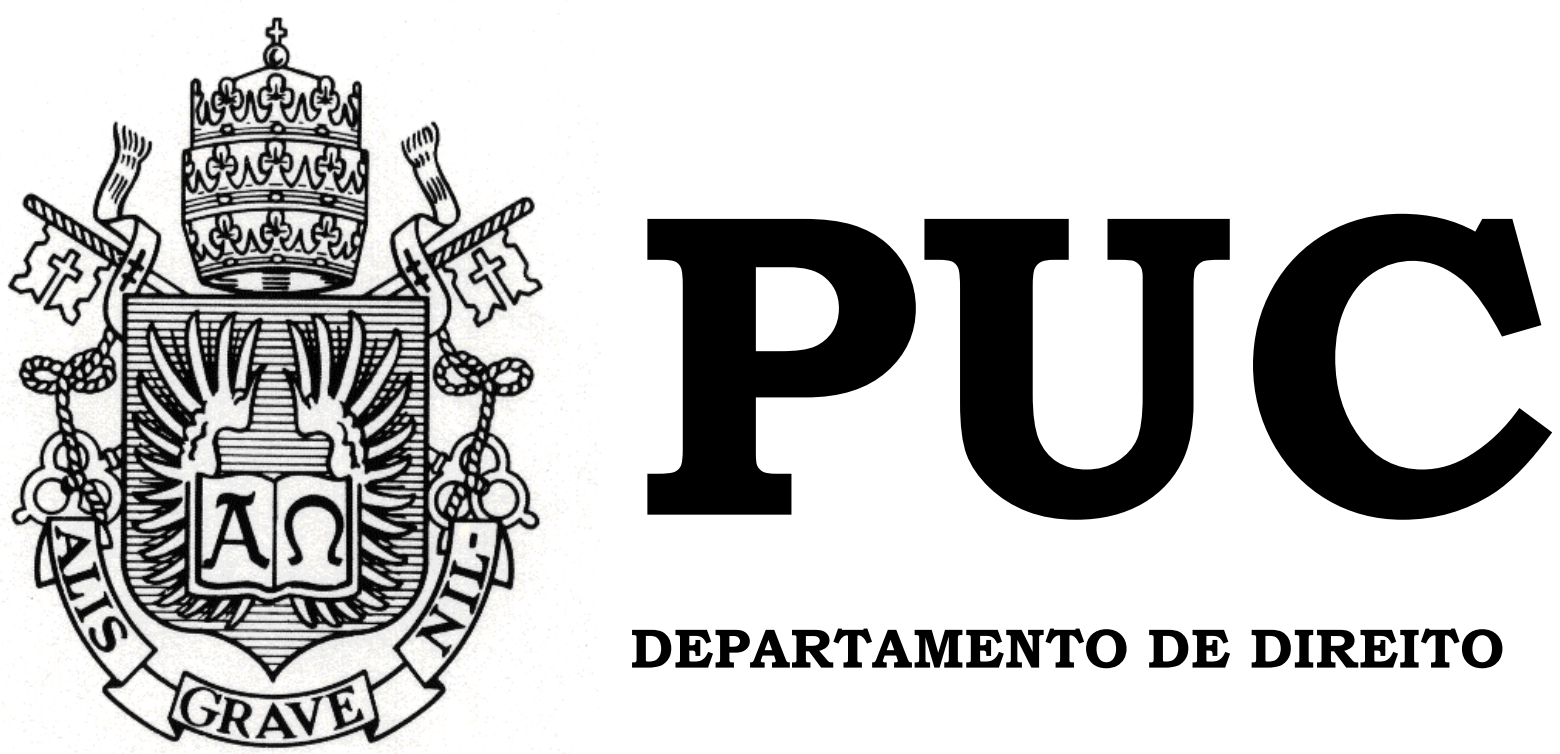

DEPARTAMENTO DE DIREITO

\title{
OFERTA PÚBLICA DE AQUISIÇÃO DE AÇÕES PARA CANCELAMENTO DE REGISTRO DE COMPANHIA ABERTA
}

Por

LOUISE CAMPELO WEST

ORIENTADOR: Francisco Antunes Maciel Müssnich

2015.2

PONTIFÍCIA UNIVERSIDADE CATÓLICA DO RIO DE JANEIRO

RUA MARQUÊS DE SÃO VICENTE, 225 - CEP 22451-900

RIO DE JANEIRO - BRASIL 


\title{
OFERTA PÚBLICA DE AQUISIÇÃO DE AÇÕES PARA \\ CANCELAMENTO DE REGISTRO \\ DE COMPANHIA ABERTA
}

\author{
por \\ Louise Campelo West
}

Monografia apresentada ao Departamento de Direito da Pontificia Universidade Católica do Rio de Janeiro (PUC-Rio) para a obtenção do Título de Bacharel em Direito.

Orientador: Francisco

Antunes Maciel Müssnich 


\section{DEDICATÓRIA}

Aos meus pais, responsáveis por todas as minhas conquistas. 


\section{AGRADECIMENTOS}

Em primeiro lugar agradeço aos meus pais, Anna Márcia Campelo e Luiz West, que foram meus primeiros professores, exemplos e pilares. Dedicaram suas vidas a me educar com amor e retidão, me encorajando a sempre ir mais longe e a nunca desistir dos meus objetivos. Serei eternamente grata.

Às minhas avós, Beni West e Lucia Campelo e, em especial, ao meu avô, Oldemar Campelo, que sempre foi o meu maior admirador e incentivador, agradeço pela torcida incondicional e por toda confiança depositada em mim.

Às minhas famílias Campelo e West, agradeço por todo amor e gentileza com que sempre me trataram, em especial às minhas amadas tias Lise Campelo e Grace Campelo, grandes incentivadoras da minha carreira jurídica.

Ao meu namorado, confidente e melhor amigo, Daniel Agra, por todo o amor, paciência e companheirismo, que me fizeram crescer na esfera pessoal e profissional. Agradeço por cada segundo ao seu lado e espero têlo sempre perto de mim.

Aos meus amigos da PUC-Rio, em especial à Tainá Freitas, com quem pude compartilhar todas as dificuldades e alegrias ao longo da faculdade. Vivenciar essa experiência sem a presença de vocês com certeza tornaria os meus dias menos divertidos.

Aos meus colegas do Vieira Rezende, agradeço pela confiança depositada, pelo rigor técnico e, principalmente, pela grande oportunidade de ter feito parte da equipe do Marcelo Barbosa (Equipe MB), formada por 
advogados brilhantes e que são os principais responsáveis por despertar em mim a paixão pelo direito societário.

Aos meus colegas da Comissão de Valores Mobiliários, agradeço pela convivência diária e por todo conhecimento que levarei para sempre comigo.

Por fim, mas não menos importante, agradeço ao meu orientador, professor e primeiro chefe, Chico Müssnich, pelo privilégio de ter sido sua orientanda, aluna e estagiária no Barbosa, Müssnich \& Aragão. Oportunidade para poucos, que hoje me dá a base para continuar buscando o aperfeiçoamento constante e que fará toda a diferença pelo resto de minha carreira. 


\section{RESUMO}

WEST, Louise Campelo. Oferta Pública de Aquisição de Ações Para Cancelamento de Registro de Companhia Aberta. 2015. 63 p. Monografia (Graduação em Direito). Pontifícia Universidade Católica do Rio de Janeiro, Rio de Janeiro.

O presente trabalho tem como objetivo a análise dos instrumentos jurídicos que devem ser empregados para o cancelamento de registro de uma companhia aberta no ordenamento jurídico brasileiro. Para tanto, buscou-se inicialmente, traçar algumas considerações conceituais sobre o tema para, por fim, analisar os principais pontos envolvendo os mecanismos de proteção aos interesses dos acionistas minoritários. O cancelamento de registro de uma companhia aberta condiciona-se à comprovação de que não existem valores mobiliários de sua emissão em circulação. Por essa razão, é condição precedente e obrigatória a realização de oferta pública de aquisição das ações em circulação, garantindo o equilíbrio de forças entre acionistas minoritários e acionistas controladores.

Palavras-chaves: Direito Societário - Mercado de Capitais - Mercado de Valores Mobiliários - Oferta Pública de Aquisição de Ações - OPA Cancelamento de Registro - Fechamento de Capital - Comissão de Valores Mobiliários. 


\section{SUMÁRIO}

INTRODUÇÃO ..................................................................................................... 8

CAPÍTULO 1 - O CANCELAMENTO DE REGISTRO DE

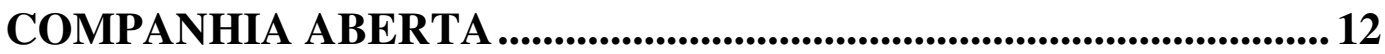

1.1. Razões determinantes para o cancelamento de registro .................... 13

1.2. Companhia aberta e companhia fechada .......................................... 15

1.3. Conceito de valores mobiliários no direito brasileiro …………….... 17

1.4. Conceito de cancelamento de registro ............................................... 19

1.5. Os efeitos do cancelamento de registro para os acionistas minoritários.

CAPÍTULO 2 - EVOLUÇÃO HISTÓRICA E TRATAMENTO LEGAL DO CANCELAMENTO DE REGISTRO ............................... 22

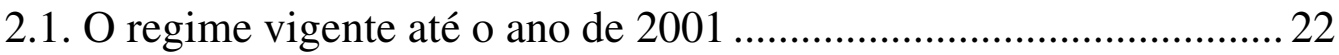

2.2. Lei 10.303 , de 31 de outubro de 2001 ............................................. 27

2.3. Instrução CVM no 361 , de 5 de março de 2002 ................................... 30

2.4. Instrução CVM no 480, de 7 dezembro de 2009 ................................. 31

\section{CAPÍTULO 3 - A OPA PARA CANCELAMENTO DE REGISTRO}

DE COMPANHIA ABERTA ....................................................................34

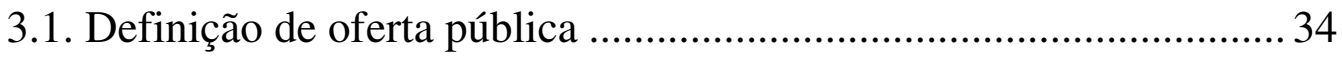

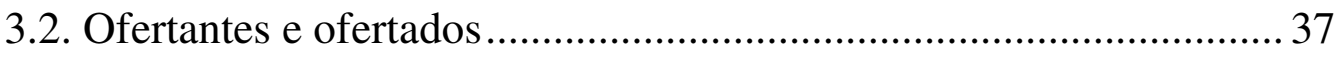

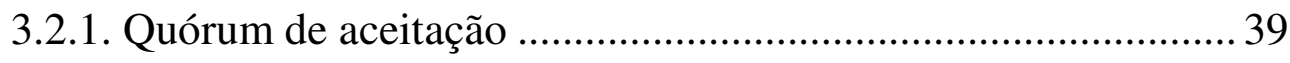

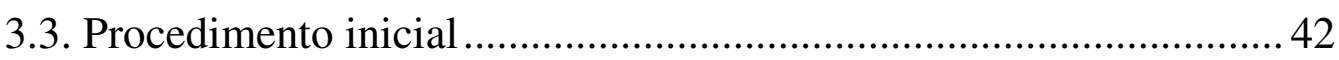

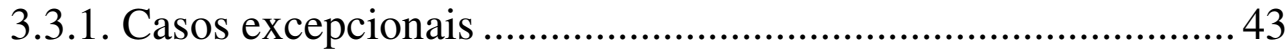

3.4. Critérios para determinação do preço de aquisição ............................ 45

3.5. Revisão do preço ofertado ............................................................... 47

CAPÍTULO 4 - ASPECTOS CONTROVERSOS ..................................... 49

4.1. "Fechamento branco" de capital......................................................... 49

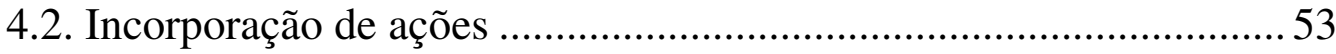

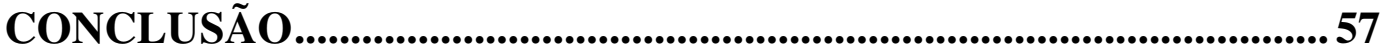

REFERÊNCIAS BIBLIOGRÁFICAS ................................................59 


\section{LISTA DE SIGLAS E ABREVIAÇÕES}

AGE

Art.

BM\&FBovespa

CVM

Instrução CVM

IPO

Lei das S.A.

Novo Mercado

OPA

S.A.

SEC
Assembleia Geral Extraordinária

Artigo

Bolsa de Valores, Mercadorias e Futuros de São Paulo

Comissão de Valores Mobiliários

Instrução normativa emitida pela CVM

Initial Public Offering ou Oferta Pública Inicial

Lei 6.404, de 15 de Dezembro de 1976 (Lei das Sociedades por Ações)

Segmento de Listagem de companhias abertas na BOVESPA

Oferta Pública de Aquisição de Ações

Sociedade por Ações

U.S. Securities and Exchange Commission - órgão regulador do mercado de ações norte-americano 


\section{INTRODUÇÃO}

O cancelamento do registro de uma companhia aberta se concretiza através do procedimento mediante o qual uma companhia aberta torna-se fechada ao adquirir a totalidade de suas ações em circulação ${ }^{1}$, inviabilizando a negociação dos valores mobiliários de sua emissão no mercado de valores mobiliários.

A decisão sobre a abertura ou fechamento de capital de uma companhia é de caráter eminentemente empresarial, privado, cabendo unicamente aos acionistas da companhia decidir sobre as vantagens e desvantagens de abrir o capital ou de cancelar o seu registro de companhia aberta (CARVALHOSA; EIZIRIK., 2002, p. 42).

Ao abrir seu capital, a companhia ingressa no mercado de capitais, que the possibilita financiar seus projetos de desenvolvimento com recursos normalmente mais baratos do que poderia obter mediante empréstimos junto a instituições financeiras. Para os seus acionistas, a principal vantagem da manutenção do status de companhia aberta consiste na liquidez dos valores mobiliários (CARVALHOSA; EIZIRIK., 2002, p. 43).

Por outro lado, a condição de companhia aberta implica uma série de custos, decorrentes, entre outros, da publicação de atas, fatos relevantes, comunicados ao mercado, da contratação de auditoria independente, da manutenção de um departamento de relações com investidores, do pagamento das taxas cobradas pela CVM e pela Bolsa de Valores etc ${ }^{2}$.

\footnotetext{
${ }^{1}$ Segundo o artigo $3^{\circ}$, inciso III, da Instrução CVM n ${ }^{\circ}$ 361, de 5 de março de 2002, “[são] ações em circulação: todas as ações emitidas pela companhia objeto, excetuadas as ações detidas pelo acionista controlador, por pessoas a ele vinculadas, por administradores da companhia objeto, e aquelas em tesouraria".

${ }_{2}^{2}$ Em 2005 a BOVESPA publicou um estudo que estimou que tais custos variavam entre $\mathrm{R} \$ 200$ mil e R\$ 2 milhões, dependendo do porte da Companhia.
} 
O contexto no qual o mercado de capitais brasileiro esteve inserido nos últimos anos relacionava-se a um contínuo movimento em prol da

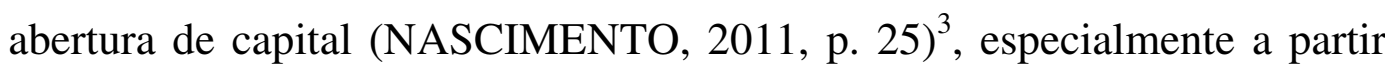
do boom de 2007, em que 64 companhias, na ânsia por aproveitar as boas condições de mercado à época, recorreram, pela primeira vez, ao mercado de captação de investimentos (OLIVEIRA, 2012, p. 194).

No entanto, a oferta pública de aquisição de ações para o cancelamento de registro de companhia aberta ganha maior relevância quando se observa que atualmente, um número crescente de companhias opta por fechar seu capital (OLIVEIRA, 2012, p. 195) ${ }^{4}$, enquanto há uma redução numérica de IPOs realizados no Brasil.

Sem dúvida, contribuiu para tal fenômeno a reduzida dimensão do mercado de capitais brasileiro, que faz com que o montante de recursos que as companhias abertas possam eventualmente captar mediante a emissão pública de valores mobiliários seja insuficiente para atender as suas necessidades (CARVALHOSA; EIZIRIK., 2002, p. 45).

Percebeu-se também que no curso do processo de abertura da economia brasileira aos investidores estrangeiros, diversas companhias tiveram o seu capital fechado após a aquisição de seu controle acionário por multinacionais, as quais, em regra, são abertas em seus países de origem, não demonstrando qualquer interesse em manter suas subsidiárias locais no mercado de valores mobiliários no Brasil.

\footnotetext{
3 "Durante o último trimestre de 2008 e primeiro trimestre de 2009 a crise econômica mundial impactou em redução do número de aberturas de capital e ofertas públicas de distribuição de valores mobiliários realizadas. Entretanto, o segundo semestre de 2009 apresentou retomada do processo de crescimento, mas ainda sem o mesmo grau de aceleração observado entre janeiro de 2004 e setembro de 2008.".

${ }^{4}$ Vale destacar comentário de OLIVEIRA acerca do crescente número de OPA para cancelamento de registro no Brasil: "Não obstante os altos índices de cancelamentos apontados, é valido destacar que existem ainda diversas companhias com ações listadas em bolsa que possuem, na verdade, baixíssima dispersão acionária, acarretando aos seus poucos minoritários baixa liquidez nos papéis por eles detidos. Esta sociedade trata-se de companhia aberta que não corresponde às necessidades dos minoritários no que tange a negociabilidade de ações, em razão da concentração do capital social da figura dos controladores, resultando em uma companhia aberta com características muito próximas de uma companhia fechada.".
} 
Além disso, nota-se que, dentre as companhias que optam pelo cancelamento de registro, a grande maioria não possui representatividade no mercado: suas ações apresentam desempenho insatisfatório, são pouco negociadas e, consequentemente, possuem baixa liquidez, ou seja, em determinado momento, o status de companhia aberta tornou-se desvantajoso do ponto de vista financeiro ou administrativo (OLIVEIRA, 2012, p. 195).

O grande dilema presente nas operações de fechamento de capital reside na divergência entre as opiniões do acionista controlador e dos acionistas minoritários. Assim, apesar da decisão de cancelar o registro de companhia aberta, na maioria dos casos, partir da administração da companhia, a opinião dos minoritários não deve ser descartada, pois estes participaram do financiamento da companhia e assumiram parte do risco do negócio.

Nesse contexto, a existência de normas que disciplinam a OPA para cancelamento de registro ganha enorme relevância e torna-se essencial para o desenvolvimento do mercado de capitais e a tutela dos interesses dos acionistas minoritários.

Assim, reconhecendo a importância do tema no cenário jurídicoeconômico brasileiro, o presente trabalho tem como principais objetivos (i) investigar algumas das principais razões pelas quais as companhias brasileiras vêm fechando seu capital, (ii) analisar as etapas e procedimentos da OPA para cancelamento de registro para (iii) verificar se tal mecanismo se mostra eficaz, garantido a proteção dos interesses dos acionistas minoritários. Desse modo, busca-se contribuir para o fomento do mercado de capitais nacional.

Este trabalho não abordará outras modalidades de cancelamento de registro de companhia aberta, tais como o cancelamento voluntário, mediante deliberação em assembleia, e o cancelamento de ofício realizado pela CVM. O escopo é, portanto, a OPA obrigatória, realizada como 
condição do cancelamento do registro de companhia aberta, visando o "fechamento de capital".

Para tanto, o Capítulo 1 explicitará algumas das principais razões pelas quais companhias brasileiras cancelam seu registro de companhia aberta, levando em consideração seu cenário econômico financeiro como fator determinante para a tomada de decisão quanto ao cancelamento de registro.

O capítulo 2 fará uma análise histórica das regras que regularam o cancelamento de registro de companhia aberta ao longo dos anos, estudando as principais inovações no que tange a proteção dos acionistas minoritários e a administração das companhias. Neste capítulo buscar-se-á entender como a Lei das S.A. procurou regulamentar, ao longo do tempo, tal procedimento respeitando os limites à intervenção da CVM.

Mais adiante, o capítulo 3 trará o conceito de OPA para cancelamento de registro e seus procedimentos necessários, decorrentes da Lei das S.A. e da Instrução CVM no 361 , desde a publicação do edital de oferta até o momento em que é concretizada, abordando a formação do "preço justo" e a possibilidade de os acionistas minoritários impedirem a realização de tal oferta. Objetiva-se analisar se tais procedimentos são eficientes para garantir a lisura da operação de fechamento de capital, evitando lesão ao patrimônio de quaisquer das partes envolvidas.

Por fim, o Capítulo 4 tratará sobre aspectos controversos em relação ao cancelamento de registro de companhia aberta, como o chamado "fechamento branco", mecanismo utilizado por companhias na tentativa de burlar a obrigatoriedade de realização de OPA para cancelar seu registro e, após, será analisada a decisão da CVM sobre incorporação de ações, que encerrou a divergência sobre a necessidade ou não de se realizar OPA para cancelamento de registro nesta última hipótese.

\footnotetext{
${ }^{5}$ Por força do $\S 4^{\circ}$ do art. $4^{\circ}$ da Lei ${ }^{\circ} 6.404$, de 1976 e do $\S 6^{\circ}$ do art. 21 da Lei no 6.385 , de 1976.
} 


\section{CAPÍtULO 1 - O CANCELAMENTO DE REGISTRO DE COMPANHIA ABERTA}

Um dos principais motivos que leva uma companhia a abrir seu capital é o acesso a recursos, em regra mais baratos do que se obtivesse empréstimos junto a instituições financeiras, para financiar projetos de investimento. Também há uma considerável redução de risco para a companhia, que se torna menos vulnerável à volatilidade econômica.

Outros objetivos almejados são a liquidez patrimonial, transformando as ações de emissão da companhia em dinheiro no momento da abertura de capital ou negociando na Bolsa de Valores, além da possibilidade de usar as ações como pagamento em aquisições e de ter um melhor referencial de avaliação da companhia - através da cotação de suas ações.

BRUM considera que a principal vantagem da abertura de capital é a possibilidade de se criar uma fonte perene de recursos para investimento, elencando ainda outras vantagens:

No momento em que abre o capital e capta recursos junto ao público, a empresa passa a trabalhar com recursos não exigíveis. Nesse momento a empresa tem condições de se desenvolver melhor, sem se endividar. (...) Outra vantagem natural e importante da abertura é a liquidez patrimonial. No momento em que as ações passam a ser cotadas e negociadas em Bolsa de Valores, o próprio mercado faz uma avaliação da empresa. (...) Dispondo de mais recursos, a empresa pode investir mais, beneficiando-se da economia de escala. ... A empresa passa a separar a administração do controle acionário, isto é, profissionaliza a administração (BRUM, 2007, p. 15-16).

Considerando tais vantagens, por que uma companhia decide fechar seu capital? 


\subsection{Razões determinantes para o cancelamento de registro}

A decisão sobre o cancelamento de registro de companhia aberta é de caráter eminentemente empresarial, cabendo a seus controladores e administradores interpretar o cenário econômico e financeiro no qual se insere a companhia para que julguem se a companhia deve ou não se manter no status de companhia aberta.

Apesar da aparente discricionariedade, as razões que levam as companhias brasileiras a retirarem suas ações de circulação nos mercados regulamentados de valores mobiliários foram objetos de inúmeras análises e pesquisas.

Diante da observação dos editais de oferta pública, percebeu-se que tais razões se misturam e até se repetem, dentre as quais se destacam três grandes grupos relacionados a custos, reestruturações societárias e à impossibilidade ou desnecessidade de captação de recursos no mercado (SIQUEIRA, 2010, p. 28).

Para CORDEIRO FILHO, as principais desvantagens do status de companhia aberta, levadas em consideração para o encerramento da negociação de seus valores mobiliários no mercado, seriam as seguintes:

1 - Informações que a administração não gostaria de trazer a público terão que se tornar disponíveis aos investidores. Em alguns tipos de negócios, é ponto nevrálgico habilitar os concorrentes a conhecer os lucros da empresa (...)

\section{$(\ldots)$}

2 - Uma série de consequências legais e práticas estão atadas à abertura. (...) Como quadro geral, essas consequências tiram flexibilidade operacional e administrativa às companhias abertas, em certas circunstâncias e com respeito a determinadas atitudes empresariais. (...)

3 - Distribuição de dividendos em fases de crescimento, ou em situações de dificuldade (que a prudência aconselha não revelar a público), somente para atender a acionistas "externos" pode ser um fator desencorajador de uma abertura. 
4 - As contrições na flexibilidade da empresa e dos controladores da companhia aberta não se operam apenas pelas consequências legais, mas também, pelas conveniências de mercado, a se refletirem na cotação das ações (ou debêntures).

5 - Dependendo da divisão adotada entre ações ordinárias e preferenciais, na estrutura do capital social, a empresa aberta que esteja necessitando de recursos pode ter como única alternativa lançar também ações ordinárias, afetando, assim, o controle dos empresários sobre sua empresa (CORDEIRO FILHO, 1981, p. 44).

\section{MOREIRA concluiu que:}

As razões que determinam o fechamento de capital extrapolam o universo jurídico, residindo especialmente na seara econômica. Assim, as condições do mercado de capitais em dado momento, que o tornam receptivo ou repulsivo aos títulos da companhia, afetam de modo particular cada uma delas, dependendo de seu setor de atuação, faturamento, estrutura de capital, dentre outros (MOREIRA, 2006, p. 118).

Assim, foi necessário desenvolver um regulamento que dispusesse sobre o cancelamento de registro de companhia aberta, em consonância com os avanços do mercado de capitais brasileiro, e que garantisse a tutela dos interesses dos acionistas minoritários.

Nesse sentido, CARVALHOSA evidencia a importância de se conferir proteção aos acionistas minoritários e ao mercado de capitais, devido ao fato de que:

(...) Os investidores, ao adquirirem ações de emissão de determinada companhia aberta, fazem-no com a convicção de que poderão negociá-las posteriormente no mercado (liquidez) bem como de que a companhia divulgará as informações necessárias à tomada de decisão quanto à conveniência de manter ou não seu investimento. Em princípio, nenhum investidor consciente se disporia a aplicar recursos no mercado acionário caso o cancelamento de registro de companhia aberta ficasse submetido à decisão discricionária dos acionistas controladores da sociedade, sem que lhe fosse assegurado o direito de desfazer-se das ações. Com efeito, a aquisição de ações de companhia aberta é justificada, sobretudo, pelo atributo da liquidez de tais valores mobiliários.

Isto posto, as normas referentes ao cancelamento de registro de companhia aberta possuem dois objetivos fundamentais: 1) conferir aos minoritários titulares de percentual relevante de ações a possibilidade de impedir o fechamento de capital da companhia; e 2) assegurar a todos os minoritários a possibilidade de alienar suas ações por preço conveniente, de sorte a não os compelir a manter-se acionistas de uma companhia cujas ações não possuam liquidez no mercado e que 
não esteja obrigada a prestar informações mínimas aos investidores (CARVALHOSA, 2002, p. 168-169).

\subsection{Companhia aberta e companhia fechada}

É fundamental para melhor compreensão do processo de cancelamento de registro de companhia aberta, ou "fechamento de capital", examinar as principais distinções entre companhia aberta e fechada, partindo da redação do caput do art. $4^{\circ}$ da Lei das S.A.:

Art. $4^{\circ}$. Para os efeitos desta Lei, a companhia é aberta ou fechada conforme os valores mobiliários de sua emissão estejam ou não admitidos à negociação no mercado de valores mobiliários.

CARVALHOSA analisa historicamente as companhias abertas e fechadas, dizendo que não havia distinção entre elas antes da Lei das S.A., vigente a partir de 1976, ao passo que, à época, o "modo de organização, de funcionamento e de controle das companhias era uniforme" (CARVALHOSA, 2002, p. 192).

Mais adiante, o autor esclarece o conceito de companhia fechada à luz da Lei das S.A.:

O regime adotado pela Lei 6.404 , de 1976, é o de financiamento da sociedade. Se esta obtém recursos de capital mediante a subscrição de ações pelos próprios acionistas ou por um grupo restrito de pessoas, mediante o exercício do direito de preferência dos acionistas ou de contrato de participação acionária, celebrando com terceiros subscritores, previamente conhecidos, temos uma sociedade fechada.

Entende-se, nesses casos de financiamento da companhia pelos próprios acionistas ou por grupo previamente conhecido de terceiros subscritores, que estes podem tutelar seus interesses no próprio âmbito contratual, dispensando, consequentemente, a tutela dos subscritores do capital e dos investidores em títulos de sua emissão.

Nessa categoria incluem-se as sociedades nas quais grupos financeiros assumem uma participação acionária, pois presume-se que, melhor do que qualquer outro grupo de acionistas, os bancos sabem defender diretamente seus interesses perante a sociedade (CARVALHOSA, 2002, p. 111-112). 
Por outro lado, CARVALHOSA define que a sociedade que busca se financiar junto ao público irrestrito é a companhia aberta, para a qual a lei estabelece regime especial de tutela do Poder Público em favor daqueles que nela investem e explica:

Quando, por outro lado, a companhia procura recursos de capital próprio (ações) ou de terceiros (debêntures) junto ao público, oferecendo a qualquer pessoa desconhecida ações e debêntures de sua emissão, temos uma companhia aberta.

Nesse caso, em face da multiplicidade dos tomadores de valores mobiliários emitidos pela companhia, que se presumem incapazes de formar uma comunidade apta a defender eficazmente seus interesses perante aquela, seus controladores e administradores, a lei estabelece um regime especial de tutela do Poder Público em favor dessa coletividade de acionistas, debenturistas e demais portadores de títulos emitidos pela respectiva companhia (CARVALHOSA, 2002, p. 112).

\section{Não obstante, BULHÕES PEDREIRA afirma que:}

Os mecanismos de funcionamento interno das companhias abertas e fechadas são os mesmos, mas, nas relações com o público as companhias abertas assumem obrigações relevantes e específicas com os participantes dos mercados de valores mobiliários, e o público em geral.

Com efeito, a diferença mais importante entra a companhia fechada e a aberta é que esta além das relações (internas) com os investidores do mercado que seus acionistas, mantém - pelo fato de participar do mercado como emissora de valores mobiliários negociados mediante oferta pública - relações com todos os investidores do mercado - inclusive os que não são titulares de valores de sua emissão, mas apenas adquirentes em potencial desses valores (LAMY FILHO; PEDREIRA, 1997, p. 84).

Quanto à companhia fechada sob a ótica da realidade brasileira REQUIÃO analisa:

Não se tem mais constrangimento em afirmar que a sociedade anônima fechada é constituída nitidamente cum intuitu personae. Sua concepção não se prende exclusivamente à formação do capital desconsiderando a qualidade pessoal dos sócios. E no nosso país, com efeito, prevalece a sociedade anônima constituída tendo em vista o caráter pessoal dos sócios, ou a sua qualidade de parentesco, e por isso chamada de sociedade anônima família. (...) A affectio societatis surge nessas sociedades com toda a nitidez, como em qualquer outra das sociedades de tipo personalista. Seus interesses estão, pois, regulados pelo contrato. O que explica a pouca ingerência da fiscalização de órgãos públicos em seus negócios (REQUIÃO, 1998, p. 31 e 32). 
Por fim, CARVALHOSA complementa o pensamento sobre a ingerência do Poder Público sobre as companhias abertas:

\begin{abstract}
No plano contratual, a diferença de disciplina legal opera-se tanto na organização como no funcionamento da sociedade. Assim, a estrutura estatutária da companhia aberta é fundamentalmente mais complexa do que a da companhia fechada. Também a atividade empresarial da companhia é submetida a um sistema especial de publicação e revelação (CARVALHOSA, 2002, p. 113).
\end{abstract}

Entretanto, o novo regime legal instituído pela Lei 10.303/01, a qual será estudada no Capítulo 2, rompeu com a dicotomia absoluta entre companhias abertas e companhias fechadas ao admitir níveis diferenciados de regulação entre as companhias abertas (CARVALHOSA; EIZIRIK., 2002, p. 40).

\title{
1.3. Conceito de valores mobiliários no direito brasileiro
}

Para o direito societário brasileiro, é de suma importância o conceito de valor mobiliário, pois delimita a competência da Comissão de Valores Mobiliários e contribui para a compreensão do que seja uma companhia aberta e uma companhia fechada.

O alcance da fiscalização não se limita às companhias abertas, mas também a qualquer emissor de valores mobiliários, e nesse sentido é a lição de EIZIRIK:

\footnotetext{
A própria lei que instituiu a Comissão de Valores Mobiliários, a Lei $\mathrm{n}^{\circ}$ 6.385/76, posteriormente alterada pela Lei $\mathrm{n}^{\circ} 10.303 / 2001$, é taxativa ao prever, no seu artigo $2^{\circ}$, parágrafo $2^{\circ}$, seu alcance tanto sobre as companhias abertas quanto sobre os demais emissores de valores mobiliários (EIZIRIK; GAAL; PARENTE; HENRIQUES., 2008, p. 26).
}

$\mathrm{O}$ art. $2^{\circ}$ da Lei $\mathrm{n}^{\circ} 6.385 / 76$, define como valores mobiliários:

I - as ações, debêntures e bônus de subscrição; (Redação dada pela Lei ${ }^{\circ}{ }^{10.303 \text {, }}$ de 31.10.2001) 
II - os cupons, direitos, recibos de subscrição e certificados de desdobramento relativos aos valores mobiliários referidos no inciso II; (Redação dada pela Lei ${ }^{\circ}$ 10.303, de 31.10.2001)

III - os certificados de depósito de valores mobiliários; (Redação dada pela Lei ${ }^{\circ}$ 10.303, de 31.10.2001)

IV - as cédulas de debêntures; (Inciso incluído pela Lei $\mathrm{n}^{\circ}$ 10.303, de 31.10.2001)

$\mathrm{V}$ - as cotas de fundos de investimento em valores mobiliários ou de clubes de investimento em quaisquer ativos; (Inciso incluído pela Lei $\mathrm{n}^{\circ} 10.303$, de 31.10.2001)

VI - as notas comerciais; (Inciso incluído pela Lei no 10.303, de 31.10.2001)

VII - os contratos futuros, de opções e outros derivativos, cujos ativos subjacentes sejam valores mobiliários; (Inciso incluído pela Lei $\mathrm{n}^{\circ} 10.303$, de 31.10.2001)

VIII - outros contratos derivativos, independentemente dos ativos subjacentes; e (Inciso incluído pela Lei no 10.303, de 31.10.2001)

IX - quando ofertados publicamente, quaisquer outros títulos ou contratos de investimento coletivo, que gerem direito de participação, de parceria ou de remuneração, inclusive resultante de prestação de serviços, cujos rendimentos advêm do esforço do empreendedor ou de terceiros. (Inciso incluído pela Lei $\mathrm{n}^{\mathbf{o}}$ 10.303, de 31.10.2001) (http://www.planalto.gov.br/ccivil_03/).

\section{A Lei $n^{\circ} 10.303$ acrescentou:}

Quando ofertados publicamente, quaisquer outros títulos ou contratos de investimento coletivo, que gerem direito de participação, de parceria ou remuneração, inclusive resultante de prestação de serviços, cujos rendimentos advêm do esforço do empreendedor ou de terceiros (http://www.planalto.gov.br/ccivil_03/).

Qualquer emissão pública de valores mobiliários distribuída no mercado deverá ser previamente registrada na CVM, entendendo-se por atos de distribuição: a venda, a promessa de venda, a oferta à venda ou subscrição, e a aceitação de pedido de venda ou subscrição de valores mobiliários. 
Os títulos das dívidas públicas federal, estadual e municipal, assim como os títulos cambiais de responsabilidade de instituição financeira (exceção feita às debêntures), não são considerados valores mobiliários, competindo ao Banco Central a regulamentação deles.

\subsection{Conceito de cancelamento de registro}

Percebe-se que a expressão "cancelamento de registro de companhia aberta" aparenta designar duas situações diversas. Em alguns momentos fala-se no sentido de um "ato administrativo" e em outro, denota-se "procedimento".

Assim, a Lei das S.A., ao dispor que "o registro de companhia aberta para negociação de ações no mercado somente poderá ser cancelado se a companhia emissora (...)" (Art. $4^{\circ}$, $\S 4^{\circ}$ da Lei das S.A ) transparece que se trata de um ato administrativo e não de um procedimento.

Por outro lado, é encontrada referência explícita a um procedimento na Instrução CVM no 361 ao dispor que nela é regulado "o procedimento aplicável a quaisquer ofertas públicas de aquisição de ações de companhias abertas, e ainda o processo de registro das ofertas públicas para cancelamento de registro de companhia aberta." (Art. $1^{\circ}$ da Instrução CVM $\left.n^{\circ} 361\right)$.

Nesse sentido, MOREIRA diferencia o cancelamento de registro entre lato sensu e stricto sensu. Designou, portanto, o procedimento para obtenção do cancelamento de registro de companhia aberta como sendo cancelamento lato sensu. Já como "ato administrativo", atribuiu a denominação de cancelamento stricto sensu (MOREIRA, 2006, p. 123).

Diante desta distinção, pode-se conceituar o procedimento de cancelamento de registro como o procedimento que tem curso perante a 
CVM, que ocorre quando o ofertante busca retirar da negociação pública no mercado de valores mobiliários a totalidade dos valores mobiliários emitidos pela companhia a qual se objetiva cancelar o registro.

O cancelamento de registro stricto sensu, por sua vez, pode ser definido como o ato administrativo pelo qual a CVM registra e confere ciência à retirada dos valores mobiliários da companhia objeto da OPA para cancelamento de registro.

A definição apresentada por MOREIRA vai além do direito empresarial e avança em direção ao direito administrativo, ao evocar o conceito de ato administrativo vinculado. Ou seja, atendidas as exigências legais e regulamentares, a CVM deve cancelar o registro da companhia objeto (MOREIRA, 2006, p. 124).

\subsection{Os efeitos do cancelamento de registro para os acionistas minoritários}

AMENDOLARA pontua a relevância do fechamento de capital de uma companhia aberta e destaca as consequências desse evento para os acionistas minoritários, ao dizer:

A decisão dos controladores de efetuarem o cancelamento de registro de companhia aberta junto à CVM é ato de extrema relevância para os acionistas minoritários, votantes ou detentores de ações preferenciais. A alteração do status de Cia. Aberta para Fechada afeta-os em três pontos que são fundamentais no mercado de capitais:

a) Perda de liquidez das ações: para alguns estudiosos desse mercado, propiciar liquidez aos valores mobiliários é a principal função das Bolsas de Valores preexistindo, inclusive, à sua organização formal, quando os corretores negociavam livremente na rua. Ora, o retorno da companhia à condição de sociedade fechada acarretará de imediato a perda de liquidez.

b) Perda do referencial de preço: a segunda função das Bolsas, em importância, é a de manter um mercado contínuo, público e transparente, em que as cotações reflitam rigorosamente a lei da oferta e da procura, decorrendo dessas premissas um preço certo, naquele momento. $\mathrm{O}$ cancelamento do registro retira do minoritário o referencial de preço, disponível teoricamente a todo momento em 
Bolsa, remetendo-o à situação de prisioneiro do valor patrimonial da empresa, às vezes de duvidosa avaliação.

c) Perda das informações relevantes: não será preciso repetir a importância para o minoritário do acesso às informações da companhia, tanto pelos relatórios da companhia, tanto pelos relatórios trimestrais e anuais que estão obrigadas a encaminhar às Bolsas de Valores e à CVM, como pela publicação de fatos relevantes. O cancelamento de registro importará na perda dessas informações pela desobrigação da empresa fechada em atender a esses dispositivos legais, exceção feita ao Balanço de encerramento do exercício.

Nessas circunstâncias só restará ao investidor vender as suas ações, a menos que, por razões particulares, deseje permanecer na sociedade (AMENDOLARA, 2003, p. 119-120).

LAMY FILHO, por sua vez, ressalta a importância de os acionistas minoritários disporem da tutela do Poder Público e dos autorreguladores do mercado de capitais, por ocasião da decisão dos controladores de companhias abertas pelo fechamento de seu capital, como se observa:

O fechamento de companhia aberta é operação das mais traumáticas para o investidor do mercado de capitais. À sua revelia, e no exclusivo interesse do controlador, o minoritário é desposado de uma característica básica do bem que adquiriu - a liquidez da sua ação - com a consequente perda de seu valor financeiro.

Trata-se, por isso, de matéria que requer tratamento extremamente rigoroso por parte das autoridades reguladoras do mercado (em nosso caso a CVM) e das bolsas de valores para prevenir abusos e fraudes que têm ocorrido em todas as latitudes (LAMY FILHO, 2007, p. 219).

Diante da necessidade de tutela aos acionistas minoritários contra abusos por parte dos acionistas controladores de companhias, diferentemente das demais modalidades de oferta, a OPA para cancelamento de registro conta com medidas de segurança específicas que visam o equilíbrio de forças entre controladores e minoritários no processo de "fechamento de capital", as quais serão estudadas deste trabalho. 


\section{CAPÍTULO 2 - EVOLUÇÃO HISTÓRICA E TRATAMENTO LEGAL DO CANCELAMENTO DE REGISTRO}

Ainda na atualidade, os investimentos em valores mobiliários no Brasil são tímidos se comparados a mercados de capitais desenvolvidos, como o americano e o inglês. Uma das principais razões que afasta os investidores do mercado de ações é a falta de credibilidade, advinda muitas vezes das manobras abusivas praticadas pelos acionistas controladores.

Nesse cenário, a reforma das normas que regulamentam a OPA para cancelamento de registro trouxe inovações na proteção dos acionistas minoritários, conferindo também maior poder à CVM e impondo maior transparência na administração das companhias.

\subsection{O regime vigente até 0 ano de 2001}

As regras para o cancelamento de registro, tal como se encontram atualmente, sofreram significativas alterações desde sua origem, que ocorreu com a criação da CVM, através da Lei $n^{\circ} 6.385$, de 7 de dezembro de $1976^{6}$, e a entrada em vigor da Lei das S.A.

A condição obrigatória ao cancelamento de registro de companhia aberta era disposta apenas em Instruções editadas pela CVM, com base legal nos incisos I e II e $\S 6^{\circ}$ do artigo 21 da Lei $6.385 / 76$, da seguinte forma:

Art. 21. A Comissão de Valores Mobiliários manterá, além do registro de que trata o Art. $19^{7}$ :

\footnotetext{
${ }^{6}$ Dispõe sobre o mercado de valores mobiliários e cria a Comissão de Valores Mobiliários.

${ }^{7}$ Art. 19. Nenhuma emissão pública de valores mobiliários será distribuída no mercado sem prévio registro na Comissão.
} 
I - o registro para negociação na bolsa;

II - o registro para negociação no mercado de balcão, organizado ou não.

$\S 6^{\circ}$ - Compete à Comissão expedir normas para a execução do disposto neste artigo, especificando:

I - casos em que os registros podem ser dispensados, recusados, suspensos ou cancelados;

A título de exemplo, a Instrução CVM $\mathrm{n}^{\circ} \quad 3$ (http://www.cvm.gov.br/export/), de 17 de agosto de 1978, primeira a tratar sobre a matéria, entre outras disposiçõos, determinava que o ofertante informasse a forma de avaliação para apurar o preço das ações de emissão da companhia:

IX - O instrumento de oferta de compra deverá conter, em sua primeira parte, os seguintes elementos:

b) o preço e as condições de pagamento;

$(\ldots)$

g) a informação de que se encontram à disposição dos acionistas minoritários, na sede da Companhia ou nos escritórios das entidades referidas no item XV, cópias das peças de avaliação do preço das ações procedida pela instituição financeira intermediária;

Em referência à Instrução CVM n ${ }^{\circ}$ 3, foi editada a Nota Explicativa $n^{\circ} 8$ (http://www.cvm.gov.br/export/), afirmando que:

O fato da CVM registrar a oferta pública não implica em que ela esteja aprovando o valor de compra oferecido por ação. $O$ registro significa que o ofertante prestou as informações necessárias, para que o investidor decida sobre a oportunidade de aceitar ou não a oferta. Cabe ao investidor, portanto, examinar as informações prestadas e fazer o seu próprio juízo sobre a oferta. 
O ex-presidente da CVM, Marcelo Trindade, discorreu sobre o surgimento da OPA para cancelamento de registro em sua manifestação de voto, no caso da OPA Voluntária da Tele Norte Leste Participações S.A. e da Telemar Norte Leste S.A., na decisão do Colegiado da Autarquia, de 29 de maio de 2007, no âmbito do Processo CVM nº RJ2007/5587, da seguinte forma:

A partir da edição da Instrução CVM 3, de 17 de agosto de 1978, surgiu uma modalidade de OPA sujeita a prévio registro na CVM, mas não expressamente prevista em lei. Tratava-se da OPA para cancelamento de registro de companhia aberta (ou fechamento de capital), exigida pela CVM com expresso fundamento no Parágrafo $6^{\circ}$ do Art. 21 da Lei 6.385, isto é, na regra segundo a qual a CVM tinha poderes para "expedir normas ... especificando casos em que os registros podem ser dispensados, recusados, suspensos ou cancelados" (inciso II do $\S 6^{\circ}$ do art. 21).

Em outras palavras: a interpretação que se deu à lei foi a de que, cabendo à CVM expedir normas sobre as hipóteses em que o registro de companhia aberta poderia ser cancelado, ela estaria autorizada a exigir a realização de prévia OPA, e de exigir que tal OPA fosse registrada perante a autarquia, sob pena de não ser cancelado o registro de companhia aberta.

Essa interpretação prevaleceu ao longo dos anos, sendo, com base nela, editadas as Instruções 185/92 e 229/95, que também trataram da OPA para cancelamento de registro de companhia aberta e exigiram seu prévio registro na CVM. (...)

A interpretação legal mais extensiva da Instrução 3 e de suas sucessoras e a interpretação muito ampliada da Instrução 299, foram ambas superadas com o advento da Lei 10.303/01. Essa lei, de um lado, instituiu expressamente a necessidade de prévia realização de OPA para o cancelamento do registro de companhia aberta, consagrando o modelo das Instruções 3, 185 e 229 (...) (http://www.cvm.gov.br/decisoes/).

Entretanto, as instruções editadas pela CVM, vigentes até o advento da Lei 10.303/01, não outorgavam aos acionistas minoritários direito à revisão do preço, conforme será estudado de forma mais aprofundada neste Capítulo.

Assim, em casos de abuso do poder de controle, restava aos acionistas minoritários apenas recorrer à via judicial para contestar o preço 
ofertado por suas ações de emissão da companhia. Consequentemente, o acionista controlador tinha a possibilidade de fixar o preço de sua oferta.

MOREIRA explica que as instruções anteriores à Instrução CVM n ${ }^{\circ}$ 361 eram insatisfatórias no que diz respeito à proteção dos interesses dos acionistas minoritários, pois "[uma vez] apresentado o preço pelo ofertante, o minoritário poderia se sentir forçado a vender suas ações àquele, sob pena de perda quase total da liquidez de seu investimento" (MOREIRA, 2006, p. 171-173).

PARENTE também fez críticas ao posicionamento da CVM à época, ressaltando que:

no caso do fechamento de capital, o controlador age como monopolista, pois é praticamente o único comprador da ação. A perspectiva da perda de liquidez afasta a interferência no leilão de terceiros a preço justo (PARENTE, In: LOBO, 2002. p. 11-49).

Essa situação, evidentemente, gerava injustiças e abusos de toda sorte. A esse respeito, PARENTE continua:

O fechamento de capital é o momento mais drástico de uma companhia em relação ao mercado de capitais. É a ocasião em que a companhia se despede do mercado onde se financiou, com a devolução aos acionistas dos recursos nela investidos. A partir desse evento, o minoritário perde a proteção da CVM, eis que a companhia deixa de sujeitar-se a diversas regras de conduta direcionadas exclusivamente às companhias abertas. Vê-se o acionista praticamente coagido a aderir à oferta pública de fechamento de capital, tendendo a aceitá-la por qualquer preço (PARENTE, In: LOBO, 2002. p. 16).

Como efeito da perda de liquidez, o valor de mercado da ação cai substancialmente, compelindo o acionista minoritário a aceitar qualquer oferta do controlador, obviamente abaixo do preço. Nesse sentido, CANTIDIANO se manifestou da seguinte forma:

A postura que tradicionalmente vinha sendo adotada pela CVM sofre muitas críticas, principalmente porque deixaria os investidores de mercado à mercê dos desejos do acionista controlador. Segundo esse entendimento, quando é decidido pelo controlador proceder ao cancelamento de registro de companhia aberta, a sociedade normalmente tem pequena parcela dos valores mobiliários de sua 
emissão sendo negociada no mercado, o que leva a uma expressiva depreciação na cotação dos títulos negociados.

Em consequência, qualquer prêmio, por menor que seja, que venha a ser oferecido pelo controlador aos demais acionistas torna atrativa a oferta formulada, na medida em que o acionista não controlador prefere se desfazer do investimento a correr o risco de permanecer como acionista de uma companhia cujas ações não terão adequada liquidez, em mercado, se ela permanecer aberta ou, o que é pior, remanescer em uma sociedade fechada que, em princípio, será menos transparente e, por isso mesmo, na qual ele terá menor proteção (CANTIDIANO, In: LOBO, 2002, p. 61-105).

MOREIRA vai além e ressalta a questão de ordem ética no que tange os esforços empregados para atrair investidores no momento do IPO da companhia:

Ora, afigura-se pouco ético a companhia fechar seu capital, presumivelmente, por não mais precisar do mercado de capitais para financiar a realização de seu objeto social, desconsiderando, ou mesmo lesando, aqueles que contribuíram para que a empresa prosperasse. Em suma, num primeiro momento, atraem-se os investidores para financiar a sociedade; num segundo momento, não sendo esses mais necessários, são descartados, sem que se preocupe com eventuais prejuízos que venham a sofrer (MOREIRA, 2006, p. 174).

\section{E CANTIDIANO continuou:}

Era evidente, segundo os especialistas, a iniquidade de tratamento dispensado aos investidores de mercado, argumentando-se que, ao contrário do que ocorre quando a sociedade procura captar recursos novos - na ocasião em que é efetivado um esforço de venda das ações novas ofertadas aos investidores - no instante em que a companhia decide cancelar seu registro perante a CVM todo o processo é conduzido de maneira hermética, sem que se apresente uma proposta justa para a recompra das ações em circulação do mercado (CANTIDIANO, In: LOBO, 2002, p. 76).

Em razão da mudança no perfil dos investidores com a evolução das companhias de capital aberto, a norma disciplinadora da matéria no Brasil sofreu sucessivas mudanças. Em sequência a CVM editou, ainda, a Instrução CVM no 185, em 1982 e a Instrução CVM nº 229, em 1995, como tentativa de adaptar a regulamentação à realidade vivida no país. 
Nas palavras de CANTIDIANO:

À época, para que se pudesse requerer o cancelamento de registro de companhia aberta era necessário haver deliberação favorável nesse sentido, adotada em AGE da companhia, pela maioria do capital social, com a posterior apresentação, pelo acionista controlador, de oferta pública de aquisição das ações em circulação no mercado.

Apresentada a oferta, que podia ou não ser condicionada ao preenchimento dos requisitos impostos pela Instrução CVM no 229/95 (com as alterações que foram introduzidas pela Instrução CVM n ${ }^{\circ} 345 / 00$ ), a CVM deferia o cancelamento do registro se, no mínimo, $67 \%$ dos destinatários da proposta de compra aceitassem alienar as suas ações ou concordassem expressamente com o cancelamento (CANTIDIANO, In: LOBO, 2002, p. 75).

Quanto à legislação vigente, embora a Lei das S.A. tivesse se apresentado como um diploma de alta qualidade técnica e de vanguarda à época em que foi concebida, modificações se fizeram necessárias. Neste particular, relevante mencionar a Lei $\mathrm{n}^{\circ}$ 9.457, de 05 de maio de 1997, a qual modificou parcialmente a Lei $n^{\circ} 6.404 / 76$ e a Lei $n^{\circ} 6.385 / 76$.

Diante do contexto de críticas à regulamentação administrativa e à liberdade dos controladores e falta de poderes da CVM, começaram a surgir propostas de mudanças da Lei das S.A.

\subsection{Lei 10.303, de 31 de outubro de 2001}

Na década de 1990, com a abertura da economia brasileira, o investimento estrangeiro no Brasil aumentou substancialmente. Concomitantemente, companhias abertas brasileiras começaram a lançar seus valores imobiliários em bolsas estrangeiras, principalmente na New York Stock Exchange.

Consequentemente, as companhias brasileiras com valores imobiliários em bolsas estrangeiras tiveram que atender ao maior rigor da SEC no que tange as informações contábeis e à maior transparência e divulgação das informações, os chamados princípios de governança 
corporativa. Paralelamente ao crescimento da participação dos investidores estrangeiros, houve um acréscimo de investimento por parte de investidores institucionais brasileiros de grande porte, mais conscientes de seus direitos.

A falta de proteção ao acionista minoritário e as incertezas com relação às aplicações financeiras foram as causas da fuga de investidores para outros mercados. Gestões não transparentes e a falta de instrumentos de supervisão sobre as companhias aumentavam a percepção de risco dos investidores, que, por sua vez, aumentava o custo de capital das companhias. Visando combater essa situação, foi aprovada a Lei $n^{o}$ $10.303 / 01$.

Objetivou-se, também, diminuir custos desnecessários das companhias abertas, uma vez que uma disciplina uniforme para todas as companhias mostrou-se inadequada, principalmente no que se refere às normas regulamentares, como as referentes à divulgação de informações, e ao dispêndio de gastos desnecessários por parte das emissoras (CARVALHOSA; EIZIRIK., 2002, p. 39).

Nesse cenário, pela primeira vez, admitiu-se a existência de níveis diferenciados de regulação entre as companhias abertas. A CVM obteve o poder de classificar as companhias abertas em categorias, segundo as espécies e classes dos valores mobiliários por ela emitidos negociados no mercado de valores mobiliários, especificando as normas que seriam aplicáveis a cada categoria.

Entretanto, como a norma do $\S 3^{\circ}$, art. $4^{\circ}$ da Lei das S.A. não seria autoexecutável, posteriormente a CVM editou a Instrução CVM n 480 por meio da qual estabeleceu duas categorias de emissores, A e B, conforme será estudado mais adiante neste trabalho.

No contexto das alterações introduzidas ao cancelamento de registro de companhia aberta, PARENTE demonstra a preocupação do legislador 
quanto à perda de liquidez das ações dos acionistas minoritários, fato que altera de modo essencial a condição da ação:

Para evitar que isso ocorra, a lei estabeleceu, no parágrafo $4^{\circ}$ do art. $4^{\circ}$, que o fechamento de capital só poderá ocorrer se a companhia emissora das ações ou o acionista controlador ou a sociedade que a controla, direta ou indiretamente, formular oferta pública para adquirir a totalidade das ações em circulação.

Deve-se atentar para o fato de que o acionista, quando subscreve o capital da empresa, paga pela ação adquirida o valor calculado tendo por base o patrimônio da companhia, ou as suas perspectivas de rentabilidade, ou o valor de cotação das ações, no caso de ações que não tem cotação significativa (Art. 170 da Lei de Sociedade por Ações). No entanto, quando o controlador decidia fechar o capital, era livre para pagar ao acionista quando lhe aprouvesse. A nova lei visa, então, assegurar um equilíbrio quando do fechamento do capital, protegendo o acionista, que é a parte mais fraca (PARENTE, 2002, p. 16).

Mais especificamente quanto à necessidade legal de realização da OPA para cancelamento de registro, claramente expressa na lei em questão, CARVALHOSA acrescenta:

Outra questão relevante - e polêmica - refere-se ao "fechamento de capital" das companhias abertas, que era, até a edição da Lei n ${ }^{\circ} 10.303$, de 2001, objeto de regulamentação administrativa da CVM, a qual obrigava o controlador a realizar oferta pública para os minoritários, mas nada dispunha sobre o preço a ser pago. A Lei $n^{\circ} 10.303$, de 2001, estabelece, na confusa redação do $\S 4^{\circ}$ do art. $4^{\circ}$, que a oferta pública para fechamento de capital deve ser formulada pelo controlador ou pela própria companhia, por "preço justo", apurado com base em um ou alguns dos seguintes critérios: patrimônio líquido contábil, patrimônio líquido a preço de mercado, fluxo de caixa descontado, comparação por múltiplos, de cotação das ações no mercado ou outro critério aceito pela CVM (CARVALHOSA, 2002, p. 92-93).

A despeito da redação do $\S 4^{\circ}$, art. $4^{\circ}$ da Lei das S.A. ter sido considerada confusa por CARVALHOSA, GALLO entende que o referido dispositivo legal é um avanço no sistema de proteção aos acionistas minoritários contra os abusos a que estão sujeitos por parte dos acionistas controladores, como se depreende de suas palavras: “Esse dispositivo legal pode ser considerado como um instrumento de defesa dos acionistas minoritários contra o poder, por vezes abusivos, do acionista controlador" (GALLO, 2011, p. 574). 
Ainda em linha com a tutela dos interesses dos acionistas minoritários no âmbito da OPA para cancelamento de registro, o art. $4^{\circ}$-A da Lei das S.A. e seus parágrafos ${ }^{8}$, também acrescentados pela Lei ${ }^{\circ}$ 10.303/01: (i) preveem as regras para o pedido da revisão do preço da OPA, por parte dos acionistas destinatários da mesma; (ii) definem as ações em circulação; e (iii) explicitam o dever de a CVM disciplinar a OPA para cancelamento de registro.

\subsection{Instrução CVM no 361 , de 5 de março de 2002}

A necessidade de aperfeiçoamento das atuais regras que regulam este tipo de operação decorreu basicamente da evolução recente do mercado de capitais brasileiro, em especial o número crescente e já considerável de companhias com controle difuso ou disperso, com a consequente necessidade de detalhamento das regras sobre OPA para aquisição de controle.

A Instrução CVM n 361 regula o procedimento aplicável a quaisquer ofertas públicas de aquisição de ações de companhias abertas, e ainda o processo de registro das ofertas públicas para cancelamento de registro para negociação de ações nos mercados regulamentados de valores

\footnotetext{
8 “Art. $4^{\circ}$-A. Na companhia aberta, os titulares de, no mínimo, 10\% (dez por cento) das ações em circulação no mercado poderão requerer aos administradores da companhia que convoquem assembleia especial dos acionistas titulares de ações em circulação no mercado, para deliberar sobre a realização de nova avaliação pelo mesmo ou por outro critério, para efeito de determinação do valor de avaliação da companhia, referido no $\S 4$ o do art. 4o.

$\S 1$ o O requerimento deverá ser apresentado no prazo de 15 (quinze) dias da divulgação do valor da oferta pública, devidamente fundamentado e acompanhado de elementos de convicção que demonstrem a falha ou imprecisão no emprego da metodologia de cálculo ou no critério de avaliação adotado, podendo os acionistas referidos no caput convocar a assembleia quando os administradores não atenderem, no prazo de 8 (oito) dias, ao pedido de convocação.

§ 20 Consideram-se ações em circulação no mercado todas as ações do capital da companhia aberta menos as de propriedade do acionista controlador, de diretores, de conselheiros de administração e as em tesouraria.

§ 3o Os acionistas que requererem a realização de nova avaliação e aqueles que votarem a seu favor deverão ressarcir a companhia pelos custos incorridos, caso o novo valor seja inferior ou igual ao valor inicial da oferta pública.

$\S 40$ Caberá à Comissão de Valores Mobiliários disciplinar o disposto no art. 4o e neste artigo, e fixar prazos para a eficácia desta revisão."
} 
mobiliários, além das modalidades de OPA por aumento de participação, por alienação de controle e para aquisição de controle.

Após a expressa previsão legal da OPA para cancelamento de registro, nos termos que em preceitua o $\S 4^{\circ}$ do art. $4^{\circ}$ da Lei das S.A., a CVM editou a Instrução CVM $n^{\circ} 361$, que entrou em vigor em 2002, e definiu a referida oferta nos seguintes termos, constantes de seu art. $2^{\circ}$, inciso I, à época:

Art. $2^{\circ}$, I - OPA para cancelamento de registro: é a OPA obrigatória, realizada como condição do cancelamento do registro de companhia aberta, por força do $\S$ $4^{\circ}$ do art. $4^{\circ}$ da Lei $6.404 / 76$ e do $\S 6^{\circ}$ do art. 21 da Lei 6.385/76. (redação original de 2002)

Ademais, a mesma instrução determinou como requisitos essenciais ao cancelamento do registro de companhia aberta pela CVM a observância das seguintes regras: (i) o preço ofertado deve ser justo (ao menos igual ao valor de avaliação da companhia) e (ii) os acionistas titulares de mais de dois terços das ações em circulação deverão aceitar a OPA ou concordar expressamente com o cancelamento do registro da companhia.

\subsection{Instrução CVM no 480, de 7 dezembro de 2009}

Apesar de expressamente disposto na Lei 10.303/01, quando a Instrução CVM n 361 foi editada, as companhias abertas não eram divididas em categorias A e B pela CVM, diferentemente do que ocorre atualmente. Assim, a OPA para cancelamento de registro era considerada pelo mercado como uma oferta para "fechamento de capital", ou seja, para voltar à condição de companhia fechada.

Atualmente, com o advento da Instrução CVM $\mathrm{n}^{\circ} 480$, as companhias abertas são registradas na CVM em uma das duas categorias: A ou B. Assim, as companhias que emitem ações, se enquadram na categoria A e são as únicas autorizadas a ter as ações de sua emissão negociadas nos 
mercados regulamentados de valores mobiliários. Já as companhias que emitem, por exemplo, debêntures, pertencem à categoria B.

A Instrução CVM n ${ }^{\circ} 480$ ainda alterou a redação constante do inciso I do art. $2^{\circ}$ da Instrução CVM 361, redefinindo a OPA para cancelamento de registro, nos seguintes termos:

Art. $2^{\circ}$, I - OPA para cancelamento de registro: é a OPA obrigatória, realizada como condição do cancelamento do registro para negociação de ações nos mercados regulamentados de valores mobiliários, por força do $\S 4^{\circ}$ do art. $4^{\circ}$ da Lei 6.404, de 15 de dezembro de 1976, e do $\S 6^{\circ}$ do art. 21 da Lei 6.385, de 7 de dezembro de 1976.

Assim, destacam-se duas características atualmente observadas na OPA para cancelamento de registro:

(i) é aplicável apenas às companhias abertas registradas na categoria A, em razão de serem as únicas com ações negociadas em mercados regulamentados de valores mobiliários; e

(ii) não tem por objetivo, exclusivamente, o conhecido "fechamento de capital", ou seja, não visa apenas ao cancelamento de registro de companhia aberta, mas, como diz a regra destacada, ao "cancelamento do registro para negociação de ações nos mercados regulamentados de valores mobiliários".

Logo, a referida OPA pode ter como finalidade tanto o cancelamento de registro de companhia aberta, o "fechamento de capital", efetivamente, quanto a migração da companhia aberta, da categoria A para a B, caso em que permanecerá na condição de companhia aberta autorizada a ter valores mobiliários de sua emissão negociados em mercados regulamentados, à exceção das ações de sua emissão?

\footnotetext{
${ }^{9}$ ICVM 480/09: "Art. $2^{\circ} \mathrm{O}$ emissor pode requerer o registro na CVM em uma das seguintes categorias:

I - categoria A; ou

II - categoria B.
} 
Entretanto, a despeito da evolução das normas e da legislação, a regulação sobre o fechamento de capital continua a sofrer duras críticas, como afirma LAMY:

A vigente regulação sobre fechamento está defasada e não atende aos objetivos que constituem a razão de ser do instituto "sociedade anônima", porque rompe o equilíbrio maioria x minoria, favorecendo o mais forte. Cabe, por isso, repensá-la e atualizá-la enquanto aos interessados e prejudicados resta a opção de ir a juízo buscar reparação do dano sofrido (LAMY FILHO, 2007, p. 220).

$\S 1^{\circ} \mathrm{O}$ registro na categoria $\mathrm{A}$ autoriza a negociação de quaisquer valores mobiliários do emissor em mercados regulamentados de valores mobiliários.

$\S 2^{\circ} \mathrm{O}$ registro na categoria $\mathrm{B}$ autoriza a negociação de valores mobiliários do emissor em mercados regulamentados de valores mobiliários, exceto os seguintes valores mobiliários:

I - ações e certificados de depósito de ações; ou

II - valores mobiliários que confiram ao titular o direito de adquirir os valores mobiliários mencionados no inciso I, em consequência da sua conversão ou do exercício dos direitos que lhes são inerentes, desde que emitidos pelo próprio emissor dos valores mobiliários referidos no inciso I ou por uma sociedade pertencente ao grupo do referido emissor." 


\section{CAPÍTULO 3 - A OPA PARA CANCELAMENTO DE REGISTRO DE COMPANHIA ABERTA}

Deliberado o cancelamento de registro de companhia aberta, o ofertante tem um dever prévio como requisito para que o "fechamento de capital" seja deferido pela CVM.

Diferentemente das outras duas modalidades de OPAs obrigatórias, a OPA para cancelamento de registro não é devida como consequência de um evento anterior, tal qual o impedimento de liquidez por parte do controlador, no caso da OPA por aumento de participação; ou alienação de controle de companhia aberta, no caso da OPA por alienação de controle).

Dada a sua natureza, então, a OPA para cancelamento de registro é a modalidade de oferta que melhor busca o equilíbrio de forças entre os acionistas controladores e os acionistas minoritários, por meio de mecanismos próprios, a serem estudados neste capítulo, que visam minimizar a coerção a que estes estão expostos por parte dos acionistas controladores.

\subsection{Definição de oferta pública}

Oferta ou proposta é um instituto jurídico com contornos próprios, trazido do direito civil, especificamente do direito dos contratos, para a disciplina do mercado de capitais.

O Código Civil, de 10 de janeiro de 2002, não define o que é proposta, mas dispõe sobre a obrigação do proponente:

Art. 427 - A proposta de contrato obriga o proponente, se o contrário não resultar dos termos dela, da natureza do negócio, ou das circunstâncias do caso (http://www.planalto.gov.br/ccivil_03/). 


\section{MONTEIRO afirma que:}

A proposta, também chamada de policitação, é o momento inicial da formação do contrato; é o ato pelo qual uma das partes solicita a manifestação da vontade da outra. Não depende em regra, como já se frisou, de forma especial e, uma vez formulada, obriga o proponente, se o contrário não resultar dos termos dela, da natureza do negócio, ou das circunstâncias do caso (MONTEIRO; MALUF; DA SILVA, 2013, p. 14).

DINIZ, por sua vez, define proposta como sendo:

Uma declaração inicial de vontade cuja finalidade é a realização de um contrato. (...) A oferta, por sua vez, traduz uma vontade definitiva de contratar nas bases oferecidas, não estando mais sujeita a estudos ou discussões, mas dirigindo-se à outra parte para que a aceite ou não, sendo, portanto, um negócio jurídico, constituindo-se em elemento da formação contratual (...)

Poder-se-á dizer então que a proposta, oferta ou policitação é uma declaração receptícia de vontade, dirigida por uma pessoa a outra (com quem pretende celebrar um contrato), por força da qual a primeira manifesta sua intenção de se considerar vinculada, se a outra parte aceitar (DINIZ, 2013).

Entende-se, portanto, proposta como um negócio jurídico unilateral pelo qual o sujeito declara a sua vontade de contratar. Mais além, a proposta será particular se for dirigida a uma pessoa ou a um grupo determinados de pessoas. De outro modo, a oferta dirigida à coletividade, de forma indiscriminada e indeterminada, será pública.

A legislação civil brasileira não fez distinção entre a proposta particular e a pública, restando apenas no art. 429 do Código Civil ${ }^{10}$ a estipulação de que, caso a oferta ao público encerre todos os requisitos essenciais do contrato, ela equivalerá à proposta (MOREIRA, 2006, p. 167).

Conclui-se que o Código Civil propõe o mesmo regramento jurídico para a oferta particular e para a oferta pública. A doutrina civilista, por sua vez, caracteriza, de forma pacifica, as OPAs como contratos de adesão, em

\footnotetext{
10 "Art. 429. A oferta ao público equivale a proposta quando encerra os requisitos essenciais ao contrato, salvo se o contrário resultar das circunstâncias ou dos usos.

Parágrafo único. Pode revogar-se a oferta pela mesma via de sua divulgação, desde que ressalvada esta faculdade na oferta realizada."
} 
que o proponente anuncia suas condições e os destinatários aceitam ou recusam a oferta. Já o ofertante vincula-se à proposta:

Dessa forma, sendo uma proposta de celebração de um negócio jurídico, a oferta produz efeitos vinculantes sobre o ofertante, o qual não pode revogá-la ou alterála unilateralmente, apenas em decorrência de sua vontade (EIZIRIK; GAAL; PARENTE; HENRIQUES., 2011, p. 540).

Entretanto, a questão ganha extrema relevância na disciplina de mercado de capitais. Nessa, a definição de uma oferta como pública tem efeitos jurídicos diferentes da oferta privada.

Assim, haverá, em síntese, a oferta pública quando esta estiver acompanhada dos seguintes critérios (EIZIRIK, 2002, p. 55-61):

a) A proposta for dirigida à generalidade de indivíduos;

b) Os ofertados não possuírem vínculos com o ofertante;

c) Os ofertados não forem investidores qualificados; e

d) Os ofertados não obtiverem acesso a informações relevantes, que a companhia deveria apresentar na hipótese de registro da oferta.

Diante do exposto, MOREIRA conceitua a oferta como "o negócio jurídico unilateral no qual o ofertante declara à coletividade de investidores indeterminados sua vontade de contratar compra, venda ou permuta de valores mobiliários." (MOREIRA, 2006, p. 171).

No âmbito da disciplina de mercado de capitais, as ofertas públicas de aquisição de ações são classificadas como obrigatórias ou voluntárias, submetendo-se às regras da Instrução CVM no 361.

As obrigatórias devem ser formuladas em decorrência de determinada operação societária, como transferência ou aquisição de controle e cancelamento de registro de companhia aberta, e necessitam de registro prévio perante a CVM. Por outro lado, as voluntárias são realizadas 
em razão da vontade de seu ofertante e são dispensadas de registro perante a CVM.

Necessário observar que apesar da relativa obrigatoriedade de realização de uma OPA quando se pretende cancelar o registro de companhia aberta, existem outras modalidades que conduzem ao mesmo resultado, todas previstas em lei e, nos regulamentos ou em diplomas legais específicos, estes últimos aplicáveis a uma ou outra companhia, isoladamente, em caráter excepcional.

Não raramente tais modalidades ocorrem quando o acionista controlador reúne os acionistas e propõe a troca de suas ações por bens imóveis, outros empreendimentos de sua propriedade ou, ainda, a permuta de ações dos minoritários por títulos emitidos por companhia fechada controlada. Caso todos os acionistas concordem, não há porque falar em OPA e, deixando de existir ações em circulação, o cancelamento de registro de companhia aberta poderá ser concedido.

Muito embora existam alternativas para a realização de determinadas operações no mercado, a sistemática das OPAs é, certamente, a mais adequada.

\subsection{Ofertantes e ofertados}

Até a promulgação da Lei 10.303 , em 2001, apenas o acionista controlador podia apresentar OPA para cancelamento de registro de companhia aberta, sendo vedado à companhia praticar qualquer ato relacionado à liquidação financeira da mesma, inclusive, quanto aos custos incorridos para a sua realização.

Atualmente, é admitido que a própria companhia, assim como seu controlador direto ou indireto, possa apresentar a OPA para cancelamento de registro de companhia aberta. 
Porém, é necessário que a OPA formulada pela própria companhia atenda seu interesse social, e não de seu controlador. Isto porque, o ato tomado em favor de terceiros poderá constituir abuso do poder de controle, conforme adverte CARVALHOSA:

A Lei 10.303 estabelece, no novo $\S 4^{\circ}$ do art. $4^{\text {o11 }}$, a possibilidade de a própria companhia promover a oferta pública de compra das ações de propriedade dos acionistas minoritários.

Trata-se de inovação criticável, uma vez que normalmente o interessado em fechar o capital da companhia é o acionista controlador, não se justificando que a companhia tenha de arcar com os custos de tal procedimento.

Assim, somente deve ser admitido que a própria companhia promova a oferta pública quando demonstrado, na assembleia geral que deliberar a respeito, que tal procedimento atende ao interesse social (CARVALHOSA, 2002).

No mesmo sentido, o art. $4^{\circ}, \S 3^{\circ}$ da Instrução CVM n n $^{\circ} 361$ condiciona a realização da OPA formulada pela própria companhia à constatação de que o procedimento será realizado no melhor interesse da companhia:

Art. $4^{\circ}, \S 3^{\circ}$ - É vedada a transferência para a companhia objeto, a qualquer título, das despesas relativas ao lançamento e à liquidação de uma OPA, salvo se a OPA for formulada pela própria companhia, nos casos admitidos em lei (http://www.cvm.gov.br/legislacao/).

\footnotetext{
11 “Art. $4^{\circ}$ Para os efeitos desta Lei, a companhia é aberta ou fechada conforme os valores mobiliários de sua emissão estejam ou não admitidos à negociação no mercado de valores mobiliários. (Redação dada pela Lei n⿳0 10.303, de 2001).

$\S 4^{\circ} \mathrm{O}$ registro de companhia aberta para negociação de ações no mercado somente poderá ser cancelado se a companhia emissora de ações, o acionista controlador ou a sociedade que a controle, direta ou indiretamente, formular oferta pública para adquirir a totalidade das ações em circulação no mercado, por preço justo, ao menos igual ao valor de avaliação da companhia, apurado com base nos critérios, adotados de forma isolada ou combinada, de patrimônio líquido contábil, de patrimônio líquido avaliado a preço de mercado, de fluxo de caixa descontado, de comparação por múltiplos, de cotação das ações no mercado de valores mobiliários, ou com base em outro critério aceito pela Comissão de Valores Mobiliários, assegurada a revisão do valor da oferta, em conformidade com o disposto no art. 4o-A. (Incluído pela Lei no 10.303, de 2001)."
} 
Considerando que a Lei das S.A. apenas permite a negociação, pela companhia, de ações de sua própria emissão, até o valor do saldo de lucros ou reservas, exceto a legal, deve ser entendido que a companhia aberta, cujo registro se pretende cancelar, pode figurar como ofertante apenas quando dispuser de reservas livres, sem o que estará sendo vulnerada a integridade do seu capital social.

\subsubsection{Quórum de aceitação}

Se a definição dos ofertados não mudou, alterou-se bastante o regramento da quantidade necessária de aceitantes, isto é, acionistas que concordam com as condições do fechamento de capital, para que a CVM realize o cancelamento do registro da companhia objeto.

Após a edição da Instrução CVM n 361 , os acionistas titulares de mais de $2 / 3$ das ações em circulação, ou free float, deverão aceitar a oferta, ou concordar expressamente com o cancelamento. Para tanto, verifica-se a ocorrência ou não do referido quórum de sucesso no resultado do leilão da oferta, uma vez que, ordinariamente, tal procedimento de leilão em bolsa de valores ou em mercado de balcão organizado é previsto para todas as modalidades de OPA.

Cabe ressaltar que, a base de cálculo para contabilizar o quórum de sucesso da OPA para cancelamento de registro considera como ações em circulação apenas as ações cujos titulares concordarem com o cancelamento ou se habilitarem para o leilão, não sendo considerados, portanto, os

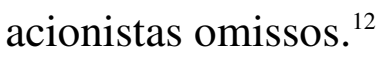

\footnotetext{
${ }^{12}$ Art. 16, II - acionistas titulares de mais de $2 / 3$ (dois terços) das ações em circulação deverão aceitar a OPA ou concordar expressamente com o cancelamento do registro, considerando-se ações em circulação, para este só efeito, apenas as ações cujos titulares concordarem expressamente com o cancelamento de registro ou se habilitarem para o leilão de OPA, na forma do art. 22.
} 
Nota-se, portanto, que não são contabilizadas as ações dos acionistas que se omitiram do processo, mas apenas as ações daqueles que manifestaram sua vontade, concordando ou discordando.

Nas palavras de SIQUEIRA, com essa regra, que também sofreu alterações desde a edição da Instrução CVM $\mathrm{n}^{\mathbf{0}}$ 3/78, primeira regulamentação da CVM a tratar dos procedimentos para o cancelamento de registro de companhia aberta:

os omissos foram neutralizados, posicionamento que, a nosso ver, foi mais adequado, exatamente porque retirou da omissão o papel decisivo no desfecho do processo (SIQUEIRA, 2010, p. 155).

A necessidade de a OPA para cancelamento de registro alcançar um quórum de sucesso aponta para o fato de que o cancelamento de registro não depende apenas de fazer o controlador prevalecer sua vontade na direção das atividades sociais e na orientação do funcionamento dos órgãos da companhia.

Diferentemente de outras matérias em que o controlador tenha esse poder de decidir sozinho, visto que faz prevalecer sua vontade nas assembleias, o cancelamento de registro de companhia aberta, uma vez decidido pelo controlador, deve ser submetido à aprovação de todos os acionistas titulares de ações em circulação, nesse caso independentemente de espécie e classe, e de as mesmas conferirem ou não direito de voto ao seu titular.

Sobre a participação dos acionistas minoritários na decisão do cancelamento de registro de companhia aberta, ressaltam-se as seguintes palavras de EIZIRIK:

Até o advento da Lei $\mathrm{n}^{\mathrm{o}} 10.303 / 2001$, os procedimentos exigidos para a realização da operação de fechamento de capital não estavam disciplinados em Lei, mas apenas em atos normativos expedidos pela CVM. 
As normas da CVM que regulavam a matéria sempre tiveram em vista a tutela dos interesses dos acionistas minoritários, de forma a impedir que as ações de sua propriedade deixassem de ser negociadas no mercado de valores mobiliários por simples vontade dos acionistas controladores ou dos administradores da companhia.

Neste sentido, para que o acionista minoritário não fosse compelido a se manter acionista de uma companhia fechada, procurou-se assegurar-lhe a possibilidade de alienar suas ações por ocasião do fechamento de capital por valor conveniente, bem como o direito de evitar o cancelamento de registro de companhia aberta, caso os acionistas contrários a tal medida representassem uma parcela substancial das ações em circulação no mercado.

Para garantir a consecução destes objetivos, as Instruções editadas pela CVM sempre estabeleceram o princípio de que, para que o registro de companhia aberta fosse cancelado, o acionista controlador deveria promover oferta pública para a aquisição das ações em circulação no mercado, que deveria ser aceita por percentual relevante dos acionistas minoritários (EIZIRIK; GAAL; PARENTE; HENRIQUES., 2011, p. 586).

Diante do poder conferido aos acionistas minoritários de impedirem o cancelamento de registro de companhia aberta, a despeito da decisão tomada pelo controlador, SIQUEIRA pontua:

(...)No fechamento de capital, o tratamento é diferente. A operação pode ser obstruída, em função de previsões legais peculiares que conferem aos titulares de ações em circulação o direito de impedir sua consecução com a simples manifestação de discordância, caso em que a S.A. permanecerá detendo a condição de aberta, frustrando-se a iniciativa do controlador-gestor (SIQUEIRA, 2010, p. 156-157).

Observe-se que a opção entre aderir ou não à OPA, bem como quanto a concordar ou não com o cancelamento de registro, é exclusiva do acionista minoritário, não podendo o responsável pela realização da OPA obrigá-lo em qualquer caso. Assim, caso prefira, o acionista minoritário poderá continuar a integrar o capital social da companhia fechada. Não terá, porém, à sua disposição, um mercado onde as ações de emissão da companhia são negociadas, pelo que não terá assegurada a possibilidade de alienar estas ações a qualquer tempo, tal qual em uma companhia aberta. 
Adicionalmente, é importante frisar que a Lei das S.A. permite que, caso remanesçam em circulação, após a realização da OPA, menos de 5\% do total das ações emitidas pela companhia, a assembleia geral poderá deliberar o resgate destas ações detidas por acionistas minoritários. Por força do resgate, os acionistas minoritários receberão o mesmo valor pago na OPA por suas ações, que serão retiradas definitivamente de circulação.

\subsection{Procedimento inicial}

A partir do momento em que a própria companhia decide pela retirada dos valores mobiliários de sua emissão de circulação, deve-se realizar a convocação do conselho de administração ou da assembleia geral extraordinária, dependendo do que dispuser o estatuto, para deliberar sobre o cancelamento de registro. Cabe ressaltar que nem a Lei das S.A., nem a Instrução CVM nº 361 são claros a respeito de qual seria o órgão social competente para a deliberação.

Não havendo expressa menção no estatuto a respeito de qual órgão é competente, MOREIRA aconselha "que a decisão seja levada à AGE, dada a gravidade da deliberação para a sociedade." (MOREIRA, 2006, p. 169).

Caso o conselho de administração ou a assembleia geral extraordinária não aprovem a proposta de cancelamento de registro, o procedimento está encerrado.

Uma vez aprovada a matéria, o passo seguinte é a publicação do fato relevante sobre a realização da oferta. Em seguida, o pedido de realização da OPA deverá ser protocolado na CVM pelo ofertante, através da instituição intermediária, no prazo máximo de 30 dias, a contar da data de publicação do aviso de fato relevante ou da deliberação que der notícia da realização da OPA, juntamente com o laudo de avaliação formulado pela instituição intermediária contratada pelo ofertante. 
Concomitantemente, a concessão do registro da OPA pela CVM ficará condicionada à obtenção de seu registro perante a bolsa de valores ou à entidade do mercado de balcão organizado em que deva ser realizado o leilão.

O pedido de registro será, finalmente, apreciado pela CVM dentro do prazo de 30 dias, contados da data do protocolo do pedido, sendo facultado à CVM, por uma única vez, formular exigências ao ofertante. Presumindose deferido se não houver manifestação da CVM naquele prazo.

Após a obtenção do registro na CVM, a OPA deve ser divulgada através de edital em jornais de grande circulação em até 10 dias. Uma vez publicado o edital, a OPA pode ser efetivada dentro de um prazo mínimo de 30 dias e máximo de 45 dias em leilão realizado sob as normas da bolsa de valores ou do mercado de balcão organizado em que as ações objeto da OPA sejam admitidas à negociação.

\subsubsection{Casos excepcionais}

O principal requisito para a concessão do cancelamento de registro de companhia aberta pela CVM é a realização de OPA para cancelamento de registro. A Instrução CVM no 361 prevê, entretanto, que há casos excepcionais em que a realização da OPA pode ser dispensada ou seguir um procedimento diferenciado.

A esse respeito, o art. 34 da referida Instrução dispõe, em rol exemplificativo:

Art. 34. Situações excepcionais que justifiquem a aquisição de ações sem oferta pública ou com procedimento diferenciado, serão apreciadas pelo Colegiado da CVM, para efeito de dispensa ou aprovação de procedimento e formalidades próprios a serem seguidos, inclusive no que se refere à divulgação de informações ao público, quando for o caso. 
$\S 1^{\circ}$ São exemplos das situações excepcionais referidas no caput aquelas decorrentes:

I - de a companhia possuir concentração extraordinária de suas ações, ou da dificuldade de identificação ou localização de um número significativo de acionistas;

II - da pequena quantidade de ações a ser adquirida frente ao número de ações em circulação, ou do valor total, do objetivo ou do impacto da oferta para o mercado;

III - da modalidade de registro de companhia aberta, conforme definido em regulamentação própria;

IV - de tratar-se de operações envolvendo companhia com patrimônio líquido negativo, ou com atividades paralisadas ou interrompidas; e

V - de tratar-se de operação envolvendo oferta simultânea em mercados não fiscalizados pela CVM.

$\S 2^{\circ}$ A CVM poderá autorizar a formulação de uma única OPA, visando a mais de uma das finalidades previstas nesta instrução, desde que seja possível compatibilizar os procedimentos de ambas as modalidade de OPA, e não haja prejuízo para os destinatários da oferta (http://www.cvm.gov.br/legislacao/).

Diante do exposto, observa-se que para que o Colegiado conceda a dispensa de realização da OPA, se faz necessário comprovar que a companhia objeto se enquadra, de fato, em uma situação excepcional, garantindo que a dispensa da oferta não seja usada como mecanismo de burlar a lei e, consequentemente, preterir os interesses dos acionistas minoritários em favor do acionista controlador.

Também no intuito de tornar os procedimentos de OPAs menos burocráticos, a Instrução confere à CVM a possibilidade de autorizar a formulação de uma única OPA, conhecida como OPA unificada, tendo por escopo mais de uma das finalidades da Instrução. Para tanto, deve ser possível compatibilizar os procedimentos das ofertas, e não pode haver prejuízo aos acionistas ofertados. 


\subsection{Critérios para determinação do preço de aquisição}

$\mathrm{O}$ ato normativo que regulou, inicialmente, o procedimento para cancelamento de registro de companhia aberta foi a Instrução CVM $\mathrm{n}^{\circ} 3$, em 1978, a qual estabelecia o conceito de preço atraente para ser utilizados nas OPAs que tinham por finalidade o cancelamento de registro.

A concepção de preço atraente, por sua vez, considerava que, para que o acionista minoritário aceitasse a proposta de alienar suas ações e, consequentemente, aprovasse o fechamento de capital, o preço de aquisição deveria ser acrescido de um ágio. Por óbvio, caso não o fizesse, o ofertante arriscaria não alcançar o quórum mínimo exigido para a realização do cancelamento de registro, perdendo seu investimento sem que o procedimento fosse concluído.

Atualmente, foi estabelecido como regra geral que o preço da OPA para cancelamento deva ser justo, isto é, deve ser igual ao valor de avaliação da companhia, apurado com base nos critérios estabelecidos, de forma isolada ou combinada, os quais CANTIDIANO esclarece nas seguintes palavras:

(a) patrimônio liquido contábil é o valor de patrimônio liquido que está registrado nas demonstrações financeiras da companhia, referenciadas a determinada data base, de livre escolha do ofertante;

(b) patrimônio liquido avaliado a preço de mercado é o valor do patrimônio líquido da companhia, que também se encontra consignado em suas demonstrações financeiras levantadas em certa data, com o ajuste, a valor de mercado, de alguns dos seus principais ativos, que estejam contabilizados por valor inferior ao de sua realização e, até mesmo, que não estejam contabilizados (como pode ocorrer, por exemplo, com uma marca de propriedade da companhia, não registrada em sua contabilidade);

(c) fluxo de caixa descontado corresponde ao fluxo de caixa futuro da companhia, descontado a uma taxa de juro que permita encontrar o valor presente do referido fluxo futuro;

(d) o método de definição do preço juto mediante a utilização de múltiplos envolve a comparação de certos valores relativos a companhias que desenvolvam 
atividades similares no mercado - como, por exemplo, o preco de aquisição de uma companhia, comparado com o numero de serviços prestados, ou o preço/lucro por ação do setor ou a divisão do valor da empresa pelo EBITDA (earnings before interest, taxes, depreciation and amortization) - aplicando-se os resultados apurados em relação à companhia que está sendo objeto da avaliação;

(e) cotação das ações no mercado de valores mobiliários corresponde ao preço de negociação, em bolsa de valores ou em mercados de balcão organizados, das ações de emissão da companhia; normalmente, para evitar que o valor de cotação das ações no mercado seja distorcido por alguma circunstância atípica ou transitória, delibera-se que será considerado o valor médio de uma serie de pregões ao longo de determinado período de tempo;

(f) com relação a outro critério que venha a ser aceito pela CVM, como estipula o texto legal, devemos aguardar a regulação ser editada para ver as soluções que serão adotadas; muito provavelmente a CVM não deverá interferir na fixação do preço que o ofertante estará disposto a pagar pela compra das ações em circulação no mercado, até mesmo para não se ver envolvida na discussão, caso a caso, do que deva ser preço justo (...) (CANTIDIANO, In: LOBO, 2002, p. 77-78).

Apesar de tais critérios objetivos, não é fácil medir o valor de uma companhia, e, por decorrência, de suas ações. Nesse sentido, GOMES DE ORNELAS busca referência na doutrina estrangeira e diz:

Então quanto vale uma sociedade em funcionamento?

Segundo Harrington, vale o preco justo que algum investidor esteja disposto a pagar pela sociedade, levando em conta o montante do retorno esperado, a época em que o retprmp será recebido e o risco inerente ao próprio retorno esperado.

Kingston e Mcquillan entendem que vale o mais alto preço obrigado no mercado, aceito por investidores prudentes, bem informados, que não realizam transações sob impulsos.

Blackman entende que as sociedades devem ser avaliadas não pelo que obtiveram no passado, mas pelo que podem ser capazes de conseguir o futuro. $\mathrm{O}$ retorno esperado, ou sua expectativa, é o fator determinante de seu valor.

Copeland, Koller e Murrin afirmam que o valor da sociedade é determinado em função de seu cash flow futuro descontado e é criado valor quando as entidades investem determinado montante de capitais cujos retornos são superiores ao próprio custo do capital aplicado. 
Temos, portanto, dois aspectos a considerar: a riqueza existente e a por vir (ORNELAS, 2001, p. 33).

Diante da gama de critérios que podem ser adotados pelo laudo de avaliação que irá apurar o valor da OPA e como forma a assegurar que os acionistas minoritários não sejam prejudicados, a Lei das S.A. e a regulamentação da CVM exigem que o preço a ser pago por ação no âmbito da OPA seja determinado por empresa especializada e com experiência neste tipo de avaliação.

Busca-se, assim, garantir ao acionista minoritário um preço justo por suas ações. O avaliador deverá utilizar no laudo de avaliação pelo menos três referências de preço e informar aquele que julgar ser o justo para efeitos da Lei das S.A.. Isto, no entanto, não vincula o Ofertante, que pode ofertar com base em outro critério.

Diante da complexidade de encontrar um critério que seja imune a dificuldades práticas, que atenda acionistas minoritários e controladores, na busca do preço justo do valor das ações emitidas pelas companhias abertas, MOREIRA pondera:

Pensamos que o mais importante não será o resultado em si aferido na avaliação, mas, sim, a lisura em seu procedimento. Caberá à CVM exercer vigilância rigorosa para que se assegure a produção de laudo com alto rigor técnico, elaborado na mais estrita boa-fé, ausente qualquer conflito de interesses entre o avaliador e a companhia objeto ou o ofertante. Dessa maneira, é possível que seu resultado seja mais facilmente aceito por todos os envolvidos, evitando-se discussões tanto dentro da sociedade quanto no Judiciário (MOREIRA, 2006, p. 164).

\subsection{Revisão do preço ofertado}

A lei admite que os acionistas de companhia aberta, que sejam titulares de, no mínimo, $10 \%$ das ações em circulação no mercado, possam requerer aos administradores da companhia que convoquem assembleia especial, para deliberar sobre a realização de nova avaliação, na qual será adotado critério diverso do adotado primeiramente pelo ofertante. 
O requerimento, a ser apresentado até o prazo de 15 dias após a divulgação do valor proposto pelo ofertante, deve estar devidamente fundamentado e acompanhado de elementos de convicção que demonstrem a falha ou a imprecisão no emprego da metodologia de cálculo ou no critério de avaliação adotado. Os acionistas minoritários que discordarem do preço da OPA podem convocar assembleia quando os administradores não a realizarem no prazo de 8 dias, a partir do pedido de convocação.

É importante destacar que, caso o resultado da nova avaliação seja igual ou inferior ao preço por ação utilizado na OPA, os acionistas que tiverem tomado à iniciativa ou que votaram favoravelmente a requerer a realização da assembleia especial deverão arcar com os custos incorridos pela companhia referentes à nova avaliação, que se referem não somente aos custos do avaliador, mas também a publicações de convocação de assembleia, ata da assembleia, entre outros.

Se o resultado da nova avaliação for melhor que o preço utilizado na OPA, este novo valor prevalecerá, facultando-se ao ofertante desistir do processo de cancelamento de registro. 


\section{CAPÍTULO 4 - ASPECTOS CONTROVERSOS}

\section{1. "Fechamento branco" de capital}

O "fechamento branco" de capital constitui, nas palavras de CARVALHOSA, expressão utilizada pelo mercado para denominar a operação na qual o acionista controlador adquire praticamente a totalidade das ações de emissão de sua controlada em circulação no mercado, sem cumprir realizar OPA para cancelamento de registro de companhia aberta perante a CVM (CARVALHOSA, 2002, p. 85).

De acordo com EIZIRIK, esse procedimento é prejudicial aos minoritários uma vez que o controlador, ao adquirir ações de emissão de sua controlada em porcentagem significativa, diminui substancialmente a liquidez das ações em circulação, sem ensejar a necessidade de OPA. Desse modo, o acionista minoritário que deseja deixar de participar da companhia se vê compelido a alienar suas ações para o controlador, já que essa seria sua única saída da companhia, permitindo que o controlador determine o preço e as condições de negociação das ações.

A Lei das S.A. dispõe as regras sobre fechamento de capital da seguinte forma:

Art. $4^{\circ}, \S 6^{\circ}-\mathrm{O}$ acionista controlador ou a sociedade controladora que adquirir ações da companhia aberta sob seu controle que elevem sua participação, direta ou indireta, em determinada espécie e classe de ações à porcentagem que, segundo normas gerais expedidas pela Comissão de Valores Mobiliários, impeça a liquidez de mercado das ações remanescentes, será obrigado a fazer oferta pública, por preço determinado nos termos do $\S 4 \mathrm{o}$, para aquisição da totalidade das ações remanescentes no mercado (http://www.planalto.gov.br/ccivil_03/). 
Como bem observa Modesto Carvalhosa:

Como se verifica, o saudável objetivo do $\$ 6^{\circ}$ do art. $4^{\circ}$ [...] é o de impedir que o acionista controlador reduza a liquidez das ações de emissão de sua controlada no mercado, em detrimento dos acionistas minoritários. Para que possa adquirir quantidades significativas de ações, o controlador deverá observar todos os procedimentos previstos para as ofertas públicas de cancelamento de registro de companhia aberta, em especial no que se refere à fixação do preço da oferta, conforme antes analisado (EIZIRIK, 2011, p. 86).

Cumprindo a tarefa de regulamentar a lei, a Instrução CVM nº 361, por seus arts. 26 a 28 , determinou que deverá ser realizada OPA por aumento de participação sempre que o acionista controlador ou pessoa direta ou indiretamente a ele vinculada, adquirir, por outro meio que não uma OPA, ações que representem mais de $1 / 3$ do total das ações de determinada espécie ou e classe em circulação (http://www.cvm.gov.br/decisoes/) ${ }^{13}$.

Essa proteção aos acionistas minoritários tem como fundamento principal o fato de que os acionistas titulares de ações da companhia que terá seu registro cancelado serão sempre prejudicados pelo fechamento de capital, uma vez que deixarão de estar protegidos pela regulamentação e fiscalização da CVM. Importante observar que as companhias abertas têm

\footnotetext{
${ }^{13}$ Nesse aspecto, ressalta-se o caso recém-julgado pela CVM, no âmbito do Processo CVM no RJ2014/3723. O processo foi instaurado pela Superintendência de Registro de Valores Mobiliários - SRE em decorrência de consulta feita à CVM pela Polo Fundo de Investimento em Ações, na qualidade de acionista minoritário do Banco Sofisa S.A. A Polo alega que os acionistas Alexandre Burmaian, Ricardo Burmaian, Cláudia Regina Burmaian e Valéria Burmaian, filhos da acionista controladora, Hilda Burmaian, vinham aumentando as respectivas participações nas ações preferenciais de emissão do Banco Sofisa desde novembro de 2008.

A Polo argumenta que tais acionistas deveriam ser considerados como integrantes do grupo de controle do Banco Sofisa ou, no mínimo, como pessoas vinculadas à acionista controladora. Assim, as mencionadas aquisições teriam ultrapassado o limite de $1 / 3$ das ações em circulação do Banco Sofisa, o que daria ensejo à realização de OPA por aumento de participação.

Em análise à Consulta, a SRE entendeu que os filhos de Hilda Burmaian deveriam ser considerados pessoas que atuam representando o mesmo interesse da acionista controladora, atendendo à definição de pessoa vinculada constante do inciso VI do art. $3^{\circ}$ da Instrução CVM n ${ }^{\circ}$ 361 e fundamentou o seu entendimento nos precedentes do Caso Baumer S.A. e do Caso Trilux Participações S.A., em que o Colegiado deliberou, por maioria, haver presunção relativa de que pertencem ao mesmo grupo de interesses do acionista controlador os seus parentes na linha ascendente e descendente, bem como os colaterais de segundo grau. Por fim, a CVM notificou a acionista controladora sobre a necessidade de que esta realizasse uma OPA por aumento de participação, nos termos do $\S 6^{\circ}$ do art. $4^{\circ}$ da LSA e do art. 26 da Instrução CVM 361, cujo procedimento ainda está sob análise da SRE.
} 
deveres e obrigações adicionais se comparadas com as companhias fechadas, devendo se pautar pelos princípios do full disclosure e da transparência. Como observam Alfredo Lamy Filho e José Luiz Bulhões Pedreira:

O cancelamento é da maior importância para os titulares dos valores mobiliários da companhia aberta, pois implica perda da liquidez própria dos valores negociados nos mercados, e da proteção de seus titulares decorrente do exercício, pela CVM, de suas atribuições legais de fiscalizar os mercados e as companhias abertas. A disciplina legal e regulamentar do cancelamento visa a proteger os interesses dos titulares de valores mobiliários em circulação no mercado (LAMY FILHO; PEDREIRA, 2009, p. 146).

Por outro lado, a CVM faculta ao acionista controlador solicitar autorização para não realizar a OPA por aumento de participação, desde que se comprometa a alienar o excesso de participação a pessoas não vinculadas no prazo de 3 meses, a contar da ocorrência da aquisição.

Note-se que compete à CVM estabelecer, por meio de normas regulamentares, a porcentagem de ações cuja aquisição caracterizará impedimento à liquidez e, consequentemente, sujeitará o controlador a realizar oferta pública para aquisição de todas as ações em circulação no mercado.

Tal porcentagem deve ser fixada em relação ao número de ações em circulação no mercado e não com base no total de ações emitidas pela companhia. Isto porque o objetivo do novo $\S 6^{\circ}$ do art. $4^{\circ}$ foi o de preservar as condições de liquidez existentes no momento da entrada em vigor da referida Instrução.

Assim, caso a CVM estabelecesse que o acionista controlador não pudesse realizar aquisições que elevassem sua participação para, por exemplo, mais de oitenta por cento das ações de cada espécie ou classe, estaria preservando apenas as condições de liquidez das espécies ou classes de ações que já se encontram extremamente concentradas nas mãos dos controladores. 
Com efeito, para as espécies ou classes que apresentam grande dispersão acionária, permitir que o acionista controlador adquira até $80 \%$ do total das ações representaria drástico impedimento à liquidez existente naquele momento.

Dessa forma, o limite de ações que o acionista controlador poderá adquirir sem ser obrigado a promover OPA deve ser estabelecido pela CVM com base em percentual das ações em circulação no mercado, e não do total das ações de cada espécie ou classe.

Por outro lado, vale salientar que, ainda que o percentual referido no novo $\S 6^{\circ}$ do art. $4^{\circ}$ seja fixado com relação ao total de ações de cada espécie ou classe, o acionista controlador não poderá ser obrigado a realizar oferta pública caso, em virtude da subscrição de aumento de capital, sua participação em cada espécie ou classe de ações seja aumentada em percentual superior ao autorizado pela CVM.

Com efeito, na hipótese de os acionistas minoritários não exercerem integralmente seu direito de preferência nos aumentos de capital da companhia, o controlador poderá aumentar sua participação no capital de sua controlada por meio da subscrição de sobras, sem que, com isso, possa ser obrigado a realizar oferta pública.

Entender o contrário praticamente inviabilizaria qualquer aumento de capital de companhia aberta, visto que, se os minoritários não exercerem o direito de preferência e não houver interesse de terceiros subscritores, o acionista controlador estaria obrigado a cancelar o aumento de capital ou a promover oferta pública para aquisição das ações pertencentes aos minoritários (CARVALHOSA, 2002, p. 86-87).

Obviamente, essa não é a finalidade do novo $\S 6^{\circ}$ do art. $4^{\circ}$, visto que não se poderia impedir o acionista controlador de financiar o desenvolvimento da companhia com seus próprios recursos. Ademais, a 
subscrição de ações em aumento de capital não interfere no número de ações em circulação e, consequentemente, não afeta a liquidez das ações no mercado.

\subsection{Incorporação de ações}

Como bem resumiu a matéria de DEL CARO na Revista Capital Aberto, "se, no fim da década de 90 e início desta, eram os casos de fechamento branco de capital que ganhavam as manchetes, agora são as incorporações que vêm gerando polêmica e descontentamento." (DEL CARO, 2010).

A regulamentação, conforme analisado anteriormente, impossibilitou o fechamento branco de capital, mas a incorporação de ações vem sendo utilizada como alternativa à OPA para cancelamento de registro. Além de se adequarem ao movimento de consolidação de vários setores da economia, elas se mostram menos dispendiosas que o cancelamento de registro.

A incorporação de ações é a operação societária por meio da qual a totalidade das ações de emissão da companhia é incorporada ao patrimônio de outra sociedade, convertendo aquela em subsidiária integral desta. Desse modo, os acionistas da companhia incorporada transferem a totalidade das suas ações para a incorporadora, que se torna a acionista única da primeira.

Nesse sentido, a incorporação de ações de uma companhia aberta, de modo a convertê-la em subsidiária integral de outra sociedade, pode ter como consequência o fechamento de capital da incorporada.

Por este motivo, durante muito tempo, questionou-se se a incorporação de ações se tratava de um negócio indireto que tinha por único objetivo o cancelamento de registro da companhia incorporada sem que 
fossem atendidos os requisitos legais necessários, dentre os quais a realização da OPA (DEL CARO, 2010).

Foi essa posição mantida por LAMY FILHO em seu parecer, nas seguintes palavras:

(...) releva-se, sem disfarce, um abuso de poder do controlador: é que o fechamento da companhia é operação da maior relevância, na medida em que os acionistas minoritários, que confiaram no mercado, são frustrados em sua confiança, passando a deter - sem que tenha sido ouvido, nem para isso concorrido - um papel sem liquidez, ou, a rigor, um outro papel. E a importância do tema é tal que uma das primeiras questões a mobilizar a atenção da Comissão de Valores Mobiliários, logo ao instalar-se, foi precisamente a do fechamento das companhias abertas (Instrução $\mathrm{CVM} \mathrm{n}^{\circ} 3$, de 17.8.78) mediante oferta pública.

\section{(...)}

Ora, fechando a subsidiaria pela via obliqua da incorporação (para o que basta constituir companhia fechada com as ações de controle), e, depois, incorporar a subsidiaria, a controladora furta-se ao império da Instrução da CVM, e agride as normas de proteção ao mercado (LAMY FILHO; PEDREIRA, 1996, p. 580).

A CVM, por sua vez, corroborou tal entendimento quando seu Colegiado determinou ser necessária a realização de OPA para a aquisição das ações detidas pelos minoritários na operação de incorporação de ações de emissão da Petrobras Distribuidora S.A. pela Petróleo Brasileiro S.A. Petrobras.

Mais adiante a CVM reviu seu entendimento a respeito de referida operação, uma vez que a Lei das S.A. passou a prever expressamente a existência deste instituto legal e não exigia o prévio cumprimento dos requisitos legais relacionados ao cancelamento de registro.

Esse entendimento pode ser confirmado quando, em 15.01.2002, a CVM examinou se a incorporação das ações da Bunge Fertilizantes S.A. e da Bunge Alimentos S.A. pela Serrana S.A. deveria ser feita através de uma oferta pública, tendo o Colegiado decidido que: 
(...) com o advento da Lei $\mathrm{n}^{\circ} 10.303$, de 31 de outubro de 2001, que introduziu alterações na Lei $n^{\circ}$ 6.404/76, as operações de incorporação de ações que envolvam sociedades controladora e controlada estão expressamente inseridas no artigo 264 da Lei ${ }^{\circ}$ 6.404/76.

$(\ldots)$

Quer isto dizer que o legislador, após inclusive ter sido proferida a decisão no Processo Administrativo ${ }^{\circ}$. RJ2000/6117 e dela tendo conhecimento, inseriu novos dispositivos ao artigo 264 da Lei $\mathrm{n}^{\circ} .6 .404 / 76$, indicando o caminho que entendia conveniente para a proteção detodos os interesses envolvidos nas operações ali tratadas, notadamente dos minoritários, do controlador e das próprias companhias em si. Afastadas as dúvidas que anteriormente existiam, passa agora a se aplicar às inteiras o artigo 264 da Lei $n^{\circ}$. 6.404/76, com as alterações da Lei $n^{\circ} 10.303 / 2001$, às operações de incorporação de ações com sociedade controlada.

Exigir-se, então, a realização de uma oferta pública como condição à realização de uma operação de incorporação, seja a clássica ou de ações, significa: (i) afastar o direito de voto do acionista controlador, o que claramente a Lei $\mathrm{n}^{\circ}$. 6.404/76 não pretendeu, ao revés, entendeu ser conveniente, conforme se verifica do artigo 264, daexposição de motivos e da opinião do Prof. Lamy (ob.cit., pág. 327); (ii) atribuir aos acionistas minoritários, titulares de ações ordinárias ou preferenciais, o direito de vetar estas operações; (iii) afastar da discussão e destas manifestações a proteção do interesse social (http://www.cvm.gov.br/decisoes/).

O entendimento que prevaleceu no Colegiado foi no sentido de que não haveria razão para que a CVM desse um tratamento diferente do que o previsto em lei. Mais ainda, não haveria razão para que a CVM tratasse a operação de incorporação de ações de sociedade controlada diferentemente da operação de incorporação "clássica" - com extinção de sociedades - pois ambas estariam sujeitas expressamente aos ditames do artigo 264 da Lei das S.A.

Recorde-se aqui, então, a razão de ser do artigo 264, na forma da exposição de motivos do anteprojeto que se converteu na Lei das S.A., da lavra dos juristas Alfredo Lamy Filho e José Luiz Bulhões Pedreira:

A incorporação de companhia controlada requer normas especiais para a proteção de acionistas minoritários, por isso que não existem, na hipótese, duas maiorias 
acionárias distintas, que deliberem separadamente sobre a operação, defendendo os interesses de cada companhia.

A solução adotada pelo Projeto pode ser assim resumida: a) a justificação da operação apresentada à assembleia geral da companhia controlada deve comparar o patrimônio das duas companhias com base no valor do patrimônio líquido, a preços de mercado (...); b) se as bases da incorporação aprovadas pela maioria da controladora forem menos vantajosas (para os acionistas minoritários da controlada) do que a comparação referida na letra anterior, os acionistas dissidentes terão direito de retirada, podendo optar pelo valor de reembolso das suas ações pela cotação de mercado (no caso de companhia aberta), ou pelo valor de patrimônio líquido contábil a preços de mercado (na companhia fechada) (art. 263, § 3..$^{\text {) }}$ (http://www.cvm.gov.br/decisoes/).

Apesar das recorrentes críticas o entendimento adotado atualmente é o de que para a realização de uma incorporação de ações deve-se apenas atender aos requisitos dispostos na Lei das S.A., sem a necessidade de cumprir os dispositivos relativos à OPA para cancelamento de registro de companhia aberta. 


\section{CONCLUSÃO}

Como se pôde ver ao longo desta monografia, analisou-se o procedimento e as consequências da OPA para cancelamento de registro de companhia aberta em seus aspectos mais relevantes e polêmicos, bem como a efetividade dos mecanismos de defesa disponíveis aos acionistas minoritários para evitar abusos praticados pelo acionista controlador ou pela companhia.

Nesse percurso, identificamos posições divergentes ao longo da história que ilustram um dissenso presente entre a CVM, o legislador e os participantes do mercado até a edição da Instrução CVM no 361 e da Lei das S.A., tal qual encontramos atualmente.

Pode-se dizer que o mercado de capitais no país ainda encontra-se em estágio prematuro, necessitando de maior regulação, objetivando o desenvolvimento econômico do país (PRADO, 2005, p. 344). Porém, embora haja críticas à atuação da CVM, é unânime a percepção de que a autarquia tem evoluído e se profissionalizado desde a sua fundação.

A proteção aos acionistas minoritários se faz extremamente necessária, pois ela constitui um sinal positivo ao investidor que, quando ausente, causa grande desestímulo ao investimento nas companhias e, em última análise, uma ameaça à sua própria liquidez. Portanto, o poder regulatório da CVM é imprescindível ao funcionamento do mercado de capitais.

Diante desse contexto, é importante que, na análise dos casos concretos, a CVM, além de julgar a obrigatoriedade de OPA tente pacificar a matéria para garantir maior grau de segurança jurídica no futuro, 
contribuindo de forma efetiva para o fomento do mercado de capitais brasileiro. 


\section{REFERÊNCIAS BIBLIOGRÁFICAS}

AMENDOLARA, Leslie. Direito dos Acionistas Minoritários. $2^{\mathrm{a}}$ ed. São Paulo: Quartier Latin, 2003.

BORBA, José Edwaldo Tavares. Direito Societário. $13^{\mathrm{a}}$ ed. (revisada e atualizada). Rio de Janeiro: Renovar, 2012.

BRASIL. 1976, Lei $n^{\circ}$ 6.385. Dispõe sobre o mercado de valores mobiliários e cria a Comissão de Valores Mobiliários. Brasília, 7 de dezembro de 1976.

BRASIL. 1976, Lei $n^{\circ}$ 6.404. Dispõe sobre as Sociedades por Ações. Brasília, 15 de dezembro de 1976.

BRASIL. 2001, Lei $n^{\circ}$. 10.303. Altera e acrescenta dispositivos na lei $\mathrm{n}^{\circ}$. 6.404, de 15 de dezembro de 1976, que dispões sobre as Sociedades por Ações e na lei $\mathrm{n}^{\circ}$. 6.385, de 7 de dezembro de 1976, que dispõe sobre o mercado de valores imobiliários e cria a Comissão de Valores Imobiliários. Brasília, 31 de outubro de 2001.

BRASIL. 2002, Lei $n^{\circ}$ 10.406. Institui o Código Civil Brasileiro. Brasília, 10 de janeiro de 2002.

BRASIL. Instrução CVM no 361 de 05 de março de 2002. Dispõe sobre o procedimento aplicável às ofertas públicas de aquisição de ações para cancelamento de registro de companhia aberta, por aumento de participação de acionista controlador, por alienação de controle de companhia aberta, para aquisição de controle de companhia aberta quando envolver permuta por valores mobiliários, e de permuta por valores mobiliários, revoga a Instrução CVM no . 229, de 16 de janeiro de 1995, a Instrução CVM n'. 299, de 9 de fevereiro de 1999 e a Instrução $\mathrm{CVM} \mathrm{n}^{\circ}$. 345, de 4 de setembro de 2000, e dá outras providências.

BRASIL. Nota Explicativa CVM $n^{\circ} 8$, de 17 de agosto de 1978. Referente à Instrução $C V M n^{\circ} 3$ de 17 de agosto de 1978 que dispõe sobre cancelamento de Registro de Companhia.

BRUM, Carlos A. H. Aprenda a Investir em Ações e a Operar na Bolsa Via Internet. 4. ed. Rio de Janeiro: Ciência Moderna, 2007. 
CAMACHO, Marilia; MAKANT, Barbara. Da utilização do instituto da incorporação de ações como meio de efetuar o fechamento de capital de uma companhia aberta sem a realização de Oferta Pública. Revista de Direito Bancário e de Mercado de Capitais. n 28. abr.-jun. 2005.

CANTIDIANO, Luiz Leonardo. Características das Ações, Cancelamento de Registro e "Tag Along". In: LOBO, Jorge (org.). Reforma da Lei de Sociedades Anônimas: inovações e questões controvertidas da Lei $\mathrm{n}^{\mathrm{o}}$ 10.303, de 31.10.2001. Rio de Janeiro: Forense, 2002.

CARVAlHOSA, Modesto. Comentários à Lei de Sociedades Anônimas: Lei $n^{\circ}$ 6.404, de 15 de dezembro de 1976, com as modificações das Leis $n^{\circ}$ 9.457, de 5 de maio de 1997 , e $\mathrm{n}^{\circ} 10.303$, de 31 de outubro de 2001. v. 1 São Paulo: Saraiva. 2002.

EIZIRIK, Nelson. A Nova Lei das Sociedades Anônimas. São Paulo: Saraiva, 2002.

CASTRO, Rodrigo R. Monteiro de; ARAGÃO, Leandro Santos de (coord.). Direito societário - Desafios atuais. São Paulo: Quartier Latin, 2009.

CHEDIAK, Julian Fonseca Peña. Reforma do Mercado de Valores Mobiliários. In: LOBO, Jorge (org.). Reforma da Lei de Sociedades Anônimas: inovações e questões controvertidas da Lei $\mathrm{n}^{\mathbf{0}} 10.303$, de 31.10.2001. Rio de Janeiro: Forense, 2002.

COMPARATO, Fábio Konder. A regra de sigilo nas ofertas públicas de aquisição de ações. In: Direito Empresarial: Estudos e Pareceres. Rio de Janeiro: Saraiva, 1990.

CORDEIRO FILHO, Ari. Manual de abertura das companhias. Rio de Janeiro: IBMEC/APEC, 1981.

DEL CARO, Luciana. Hora de dizer adeus. Revista Capital Aberto, n. Especial: Rio de Janeiro, abr.2010.

DINIZ, Maria Helena. Tratado Teórico e Prático Dos Contratos. - 5 Volumes $-7^{\text {a }}$ Ed. 2013

Disponível em:

<http://www.cvm.gov.br/decisoes/2007/20070529_R1/20070529_D11.html $>$. Acesso em: 12 jun. 2015. 
Disponível em:

<http://www.cvm.gov.br/decisoes/2014/20140520_R1.html>. Acesso em: 05 nov. 2015.

Disponível em:

$<$ http://www.cvm.gov.br/export/sites/cvm/legislacao/anexos/inst/001/inst00 3.pdf>. Acesso em: 12 jun. 2015.

Disponível em:

<http://www.cvm.gov.br/export/sites/cvm/legislacao/nota/anexos/nota008.d oc>. Acesso em: 20 out. 2015.

Disponível em: <http://www.cvm.gov.br/legislacao/inst/inst361.html>. Acesso em: 21 out. 2015.

Disponível em:

<http://www.planalto.gov.br/ccivil_03/leis/2002/L10406.htm>. Acesso em: 28 out. 2015.

Disponível em:

$<$ http://www.planalto.gov.br/ccivil_03/leis/L6404consol.htm>. Acesso em:. 21 out. 2015.

EIZIRIK, Nelson. A Lei das S/A Comentada. v. 1. São Paulo: Quartier Latin, 2011.

$\underset{\text { p. } 55-61}{ }$ Revista de Direito Mercantil, Industrial, Econômico e Financeiro.

Temas de Direito Societário. Rio de Janeiro: Renovar, 2005.

; GAAL Ariádna B.; PARENTE, Flávia; HENRIQUES, Marcus de Freitas. Mercado de Capitais: regime jurídico. Rio de Janeiro: Renovas, 2008, 2011.

GALlO, G. M., artigo. As Ofertas Públicas in Edições Especiais Doutrinas Essenciais Direito Empresarial, organizador: Arnold Wald, Voll. VIII. São Paulo: Revista dos Tribunais. 2011, p. 574.

LAMY FILHO, Alfredo. Temas de S.A. Rio de Janeiro: Renovar, 2007

PEDREIRA, Jose Luiz Bulhões. Apud. Decisão do colegiado de 15/01/2002 no âmbito do Processo Administrativo CVM nº RJ2001/11663. Disponível em: 
<http://www.cvm.gov.br/decisoes/2002/20020115_R1/20020115_D05.html >. Acesso em: 05 nov. 2015.

. A Lei das S.A. $2^{\mathrm{a}}$ ed. v. I. Rio de Janeiro: Renovar, 1996.

. A Lei das S.A. $3^{\mathrm{a}}$ ed. v. II. Rio de Janeiro: Renovar, 1997.

- Direito das Companhias. $1^{\mathrm{a}}$ ed. v. I. Rio de Janeiro:

Forense, 2009.

LAZZARESCHI NETO, Alfredo Sérgio. Lei das Sociedades Anônimas Anotada. São Paulo: Saraiva, 2006.

LODI, João Bosco. Fusões e Aquisições - o cenário brasileiro. Rio de Janeiro: Campus, 1999.

MONTEIRO, Washington de Barros; MALUF, Carlos Dabus; DA SILVA, Regina Beatriz Tavares. Curso de Direito Civil. São Paulo: Saraiva. 5o Volume, ed. 7. 2013. p. 14.

MOREIRA, Ricardo Guimarães. Sociedades Anônimas Brasileiras \& Fechamento de Capital. Curitiba: Juruá, 2006. 262 p.

NASCIMENTO, João Pedro Barroso do. Medidas Defensivas à Tomada de Controle de Companhias. São Paulo: Quartier Latin, 2011, p. 25.

OLIVEIRA, Karina Cardozo de. Fechamento do capital social: estudo de casos. Revista de Direito Bancários e do Mercado de Capitais. v. 55, out. 2012.

ORNELAS, Martinho Maurício Gomes de. Avaliação de Sociedades: Apuração de Haveres em Processos Judiciais. São Paulo: Editora Atlas, 2001.

PARENTE, Norma. Principais Inovações Introduzidas. In: LOBO, Jorge (org.). Reforma da Lei de Sociedades Anônimas: inovações e questões controvertidas da Lei $\mathrm{n}^{\mathrm{o}}$ 10.303, de 31.10.2001. Rio de Janeiro: Forense, 2002.

PERIN JUNIOR, Ecio. A Lei 10.303/2001 e a Proteção do Acionista Minoritário. São Paulo: Saraiva, 2004.

PRADO, Roberta Nioac. Oferta Pública de Ações Obrigatória nas S.A. São Paulo: Quartier Latin do Brasil, 2005. 366 p. 
REQUIÃO, Rubens. Curso de Direito Comercial. São Paulo: Saraiva, 1998.

SABILI NETO, José. Os princípios de uma vitoriosa cultura de gestão do Brasil. Entrevista com Jorge Paulo Lemann. HSM Management, jan.-fev. 08.

SIQUEIRA, Carlos Augusto Junqueira de. Fechamento de Capital: Oferta Pública de Aquisição de Ações e Outras Modalidades. Ribeirão Preto: Migalhas, 2010.

WALD, Arnoldo; GONÇALVES, Fernando; SOARES DE CASTRO, Moema Augusta (coord.); FREITAS, Bernardo Vianna; CARVALHO, Mário Tavernard Martins de (org.). Sociedades Anônimas e Mercado de Capitais. São Paulo: Quartier Latin, 2011. 